TECHNICAL TRANSACTIONS 3/2019

MECHANICS

DOI: $10.4467 / 2353737$ XCT.19.039.10213 SUBMISSION OF THE FINAL VERSION: 19/03/2019

\author{
Marcin Noga iD orcid.org/0000-0002-3738-2220 \\ noga@pk.edu.pl \\ Cracow University of Technology, Faculty of Mechanical Engineering, \\ Institute of Automobiles and Internal Combustion Engines
}

\title{
A THREE-WAY CATALYST SYSTEM FOR A FIVE-STROKE ENGINE
}

\author{
TRÓJFUNKCYJNY REAKTOR KATALITYCZNY DLA SILNIKA Z DODATKOWYM \\ ROZPRĘŻANIEM GAZÓW WYLOTOWYCH
}

\begin{abstract}
This paper presents the results of research on the development of an exhaust gas aftertreatment system for a turbocharged five-stroke engine. This engine was designed and constructed at Cracow University of Technology. A characteristic feature of the five-stroke engine is the use of an additional expansion process to increase overall efficiency. A challenge for a catalytic converter is the fact that it has a low exhaust gas temperature. Two three-way catalytic converters were tested - one with a ceramic support and the second with a metal support. The results of the tests showed that the reactor with a ceramic support obtains an acceptable conversion efficiency starting with an exhaust gas temperature of $280^{\circ} \mathrm{C}$. For the metal-support reactor, a few percent increase in torque and a decrease in the brake-specific fuel consumption of the engine was obtained; however, the converter itself did not show signs of operation even with an exhaust gas temperature of over $380^{\circ} \mathrm{C}$. The performed analyses highlighted directions of further development works in this area.
\end{abstract}

Keywords: five-stroke engine, spark ignition, three-way catalyst, exhaust gas aftertreatment, conversion efficiency

\section{Streszczenie}

W artykule przedstawiono efekty badań nad opracowaniem układu oczyszczania spalin dla turbodoładowanego silnika pięciosuwowego, który został zaprojektowany i wykonany na Politechnice Krakowskiej. Cechą charakterystyczną silnika pięciosuwowego jest zastosowanie dodatkowego rozprężania spalin w celu zwiększenia sprawności ogólnej. Wyzwanie dla reaktora katalitycznego stanowi niska temperatura spalin. Badaniom poddano dwa reaktory trójfunkcyjne, z rdzeniem ceramicznym i z rdzeniem metalowym. Wyniki przeprowadzonych prób wskazały, że reaktor ceramiczny uzyskuje akceptowalną sprawność konwersji od temperatury spalin $280^{\circ} \mathrm{C}$. Dla reaktora metalowego uzyskano kilkuprocentowy wzrost momentu obrotowego i obniżenie jednostkowego zużycia paliwa silnika, jednak sam reaktor nie wykazywał oznak działania nawet przy temperaturze spalin powyżej $380^{\circ} \mathrm{C}$. Przeprowadzone analizy wskazały kierunki dalszych prac rozwojowych w przedmiotowym obszarze.

Słowa kluczowe: silnik z dodatkowym rozprężaniem gazów wylotowych, zapłon iskrowy, trójfunkcyjny reaktor katalityczny, układy oczyszczania spalin, sprawność konwersji 


\section{Symbols and abbreviations}

\begin{tabular}{|c|c|}
\hline$\alpha_{\text {thr }}$ & - throttle opening, $\%$ \\
\hline$\alpha_{\text {ign }}$ & - ignition timing, ${ }^{\circ} \mathrm{CA}$ \\
\hline$\lambda$ & - relative air-fuel ratio, - \\
\hline $\mathrm{ABDC}$ & - after bottom dead centre \\
\hline add. & - additional \\
\hline ATDC & - after top dead centre \\
\hline $\mathrm{BBDC}$ & - before bottom dead centre \\
\hline $\mathrm{BDC}$ & - bottom dead centre \\
\hline BMEP & - brake mean effective pressure, bar \\
\hline BSFC & - brake specific fuel consumption, $\mathrm{g} / \mathrm{kWh}$ \\
\hline BTDC & - before top dead centre \\
\hline $\mathrm{CA}$ & - crank angle, $^{\circ}$ \\
\hline cyl. & - cylinder \\
\hline downstr. & - downstream \\
\hline EGT & - exhaust gas temperature, ${ }^{\circ} \mathrm{C}$ \\
\hline EVC & - exhaust valve closing, ${ }^{\circ} \mathrm{CA}$ \\
\hline EVO & - exhaust valve opening, ${ }^{\circ} \mathrm{CA}$ \\
\hline exp. & - expansion \\
\hline $\mathrm{FC}$ & - fuel consumption, $\mathrm{kg} / \mathrm{h}$ \\
\hline $\mathrm{HP}$ & - high pressure cylinder \\
\hline IVC & - intake valve closing, ${ }^{\circ} \mathrm{CA}$ \\
\hline IVO & - intake valve opening, ${ }^{\circ} \mathrm{CA}$ \\
\hline LP & - low pressure cylinder \\
\hline MBT & - Maximum Brake Torque \\
\hline $\mathrm{n}$ & - rotational speed, $\mathrm{rpm}$ \\
\hline NDIR & - nondispersive infrared \\
\hline rel. & - relative \\
\hline $\mathrm{RON}$ & - research octane number, - \\
\hline SI & - spark ignition \\
\hline $\mathrm{t}$ & - time, $s$ \\
\hline $\mathrm{T}$ & - torque, $\mathrm{Nm}$ \\
\hline TDC & - top dead centre \\
\hline temp. & - temperature \\
\hline turb. & - turbine \\
\hline TWC & - three way catalyst \\
\hline upstr. & - upstream \\
\hline $\mathrm{V}_{\mathrm{ch}}$ & - combustion chamber volume, $\mathrm{dm}^{3}$ \\
\hline $\mathrm{V}_{\text {cyl }}$ & - cylinder swept volume, $\mathrm{dm}^{3}$ \\
\hline
\end{tabular}




\section{Introduction}

More than 130 years have passed since the construction of Karl Benz's first automotive vehicle powered by an internal combustion engine [13]. Since then, combustion engines have found a wide range of applications in road, rail, sea and air transport. The spreading of internal combustion engines and sustaining their popularity was favoured, above all, due to the development of technology producing high-energy liquid fuels in the process of refining of crude oil. It can also be expected that the engines will continue to be an important source of propulsion for motor vehicles in the upcoming decades [6]. This is despite the fact that combustion engines, including those used to drive vehicles, have a number of disadvantages. Firstly, combustion engines do not have a particularly high level of efficiency with regard to converting the energy of the burned fuel into mechanical work. The operation of internal combustion engines is also associated with the emission of significant amounts of $\mathrm{CO}_{2}$ and the toxic components of exhaust gases, which entails the necessity of using expensive methods of limiting their emissions [14, 23]. Hydrocarbon fuels most often used to feed engines come from crude oil processing, the reserves of which are gradually depleting, and finding a substitute is not easy. Attempts to use alternative fuels, such as natural gas or the fuels, or their components obtained from the processing of plants are associated with many different problems of a logistical, operational or even social nature. The use of plants for the mass production of fuels may lead to an increase in food prices [3]. The use of alternative fuels does not eliminate $\mathrm{CO}_{2}$ emissions and toxic exhaust components, and only limits them to a certain extent [11]. Some hopes in this regard were associated with the use of hydrogen, which is not accompanied by $\mathrm{CO}_{2}$ emissions; however, the difficulty of storing this medium in a sufficient amount on board the vehicle and the problematic control of the combustion process makes it an unsuitable fuel for powering engines used for vehicle propulsion. With good availability in industrial conditions, hydrogen can be successfully used to feed engines that drive electricity generators [7]. In traction applications, it is definitely more efficient to use hydrogen to feed commercially available vehicles powered by electricity produced in high-efficiency, on-board fuel cells [44].

The circumstances described above mean that in the next ten to fifteen years one can expect an ongoing decline in the use of the combustion engine as the sole source of vehicle drive which, according to the contemporary global automotive development concept, is to be eventually replaced by electric motors. However, the rapid and widespread deployment of pure electric vehicles faces many problems. As has been well publicised, the use of electric drive completely eliminates the emission of carbon dioxide and toxic gases in the place of use of the vehicle, which is a totally positive benefit. However, when considering the method of generating electricity in a given area, it may transpire that the equivalent emission of carbon dioxide resulting from the use of an electric vehicle may exceed the emission generated by a modern car powered by an internal combustion engine [38]. Another key issue that is yet to be resolved is the highly limited capacity of energy storage in batteries that are currently available, which in addition, remain both expensive and heavy. Other problems with regard to extending the use of electric drives in the automotive industry are issues related to methods 
of production and the recycling of batteries. These are energy-intensive processes which, to greater or lesser degrees, constitute environmental pollutants. In some cases, these pollutants may even be toxic [15].

For the above reasons, the promotion of development of hybrid drive systems is a favourable solution for the continuous development of the automotive sector with a simultaneous significant reduction in the consumption of hydrocarbon fuels and exhaust emissions [43]. The simultaneous use of a combustion engine and electric machine for the vehicle's drive primarily enables the recovery of braking energy; additionally, it enables the specific use of an internal combustion engine which would not be possible when the combustion engine was the only source of propulsion. This concept assumes that, firstly, the combustion engine mainly works only when it is necessary, and if it is working, the algorithm of the engine management system predicts working in situations in which it achieves the highest possible levels of efficiency. In principle, regardless of the type of hybrid drive system, this usually means the operation of the engine in the high load region, close to the maximum level. In hybrid propulsion systems, it is possible to limit the idling time and the time spent working with a low load to the minimum which is required; this is where the combustion engine achieves a very low level of efficiency. In such systems, internal combustion engines optimised for work in a specific part of their operation map are used.

After many years of continuous development, the internal combustion engine is now a device that has actually been refined to close to the limit of its technical possibilities. Designers of modern internal combustion engines are looking for solutions that improve efficiency by even a fraction of a percent. Similarly, extending the area in which the engine operates close to the minimum brake specific fuel consumption by the speed range of $100 \mathrm{rpm}$ or $0.1 \mathrm{MPa}$ of brake mean effective pressure is considered a great success. Many methods of improving the efficiency of the internal combustion engine are known. Some of these are focused on limiting mechanical losses [21], others on reducing thermal losses [48]. The extension of the range in which the internal combustion engine works most effectively usually consists of the introduction of variable valve timing, variable valve lift, variable intake port length, multi-stage charging, and more recently, also in the variable compression ratio of the engine [33].

\section{Increased expansion ratio}

The application of an expansion ratio which is significantly higher than the compression ratio is one of the methods that fits in with the development trends of internal combustion engines outlined above and currently offers some possibilities in reducing fuel consumption, i.e. in increasing the efficiency of converting the thermal energy of the burned fuel into mechanical energy [39]. The use of a high expansion ratio in order to achieve high engine efficiency was observed by the inventor of the concept of a four-stroke work cycle - French engineer Alphonse Beau de Rochas and was recorded in his 1861 patent [29]. Fig. 1 presents the theoretical 1-2-3-4-1 cycle of a spark ignition engine. 


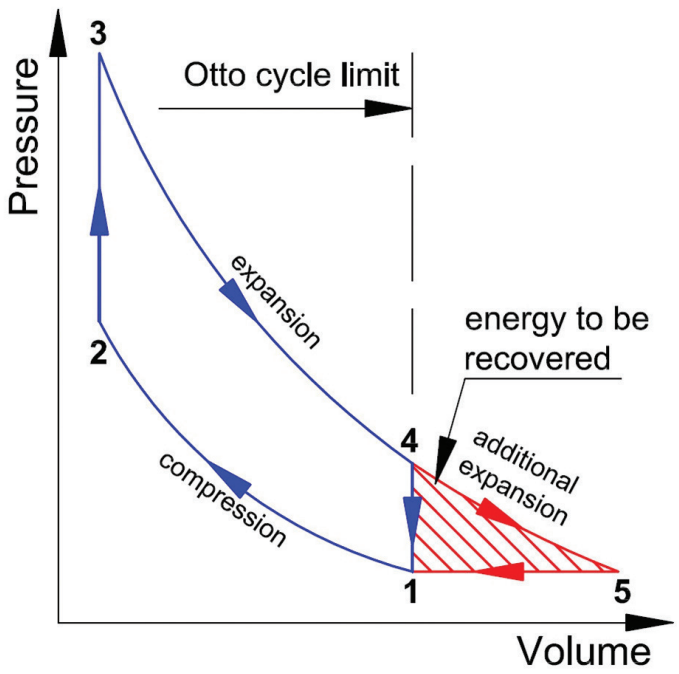

Fig. 1. Otto cycle with the marked area of work of additional expansion

In this figure, the area 4-5-1 is marked red. This refers to the heat that can be theoretically recovered in the process of the additional expansion of the exhaust gas up to the ambient pressure (pressure for points 1 and 5). In the classic Otto cycle, this heat is rejected into the environment in an isochoric process 4-1, and in the real engine, this event corresponds to the opening of the exhaust valve, while the pressure and temperature in the cylinder remain significantly higher than the ambient pressure.

As can be seen in theoretical approaches, increasing the expansion ratio of the charge over the compression ratio enables a clear reduction of engine heat losses associated with the release of hot exhaust gases into the atmosphere. In practical approaches, one should take into account many other phenomena and regularities occurring in the case of a cycle with an increased charge expansion ratio which are omitted in simple theoretical analyses. These factors have an impact on reducing the real benefits in the form of an increase in thermal efficiency. Nevertheless, the fact is that the increased expansion ratio is used in modern engines irrespective of whether they rely on spark ignition or compression ignition [30]. There are several main ways to differentiate the expansion ratio over the compression ratio. The following should be mentioned here:

1. The idea of the 19th-century English inventor and engineer James Atkinson was of a four-stroke work cycle in which the stroke length of the piston in the intake and compression strokes is clearly smaller than the stroke length in the power and exhaust strokes. Atkinson obtained such an effect in two ways. In the first engine, called "differential", the abovementioned effect was achieved by using a system of two pistons working in one cylinder and linked by a special arrangement of connecting rods. The second of Atkinson's engines, called "cycle", was more similar in its form to classic solutions. A single piston worked in the cylinder, and to achieve a differentiated stroke length in each stroke, a system of kinematic links with a split connecting rod and a pivoting connecting-rod fulcrum was used [10]. 
2. The concept of Ralph Miller, according to which the closing of the intake valve occurs significantly before the piston reaches the bottom dead centre (BDC). This means early intake valve closing comparing to the classic engine. Such control of the opening of the intake valve results in a decrease in the volumetric efficiency, internal cooling of the charge expanded in the cylinder after closing the valve until the piston reaches the $\mathrm{BDC}$, and, above all, the effective length of the compression stroke decreases, which also reduces the effective value of the compression ratio. However, in such an engine, the charge expansion process occurs at the full length of the power stroke, which causes the expansion ratio to be higher than the effective value of the compression ratio. Typically, mechanically driven compressors or turbochargers are used to compensate for the loss of engine performance caused by the reduction of volumetric efficiency in engines with early intake valve closing [31].

3. This is the concept of the delayed closing of the intake valve, in which it closes long after the piston reaches the bottom dead centre. Part of the cylinder charge is forced back to the intake manifold, thus the effective length of the compression stroke is also shortened, which, when carrying out the expansion process (as occurs in the classical engine), gives an expansion ratio that is significantly higher than the effective compression ratio.

4. This is the division of the expansion process into two working spaces similar to steam engines with multiple-expansion. In such an engine, after carrying out the classic fourstroke process, the exhaust gases are not removed to the atmosphere but instead flow to a separate cylinder with a volume significantly higher than the working cylinder. The exhaust gases are subjected to a double expansion to pressure and temperature levels that are much closer to the ambient levels than occur in the classical engine.

Among the aforementioned methods of obtaining an increased expansion ratio in the internal combustion engine, James Atkinson's original engines (in which the complex system of kinematic links prevented the achievement of a high output shaft rotational speed) should be treated as a historical solution. Nevertheless, it is worth noting that new simulation results [16] as well as experimental research on similar types of engine [12] can be found in literature. Engines obtaining an increased expansion ratio in relation to the compression ratio by means of early or late intake valve closing are currently being designed, mass produced and used not only in many automotive vehicles, but also in railway, industrial and marine applications. Typically, such engines are called Miller engines or Atkinson engines, but unfortunately, there are no strict rules for distinguishing between each of these engine types [22]. Miller's name appears rather more often. For example, engines that use early intake valve closing, usually with a charging system, are more often called Miller engines. In these engines, the charging system is used to compensate for a significant loss in volumetric efficiency. The reduction of the cylinder filling results from the earlier closing of the intake valve and also from the significantly lower cam lift that controls the intake valve. With a short valve opening period, the lift limit is the result of the allowable valve acceleration that occurs during the rise and fall phases [46]. The term "Miller engine" also refers to machines obtaining an increased expansion ratio by retarding the closure of the intake valve. This applies to both the supercharged and 
the naturally-aspirated version $[17,18]$. However, retarded intake valve closure is also applied in other scenarios, such as within a wide range of naturally-aspirated spark ignition engines used in vehicles with Toyota hybrid propulsion systems, and more recently also Hyundai-Kia. The abovementioned engines are referred to by their producers as Atkinson-cycle engines $[1,20]$. Due to the described inconsistency in the nomenclature, the term "Atkinson-Miller cycle" can also be found in the literature. This term is mainly used in theoretical works [49]. It should be mentioned here that while both Atkinson and Miller aimed to realise an increased expansion ratio of the charge, Atkinson's original idea did not adopt the use of a non-standard opening of the intake valve, which was a fundamental assumption of Ralph Miller [32]. In the light of this fact, it can be argued that engines that are currently produced which perform a cycle with an increased expansion ratio should be named after Ralph Miller rather than James Atkinson.

A different way of increasing the expansion ratio is realised in engines with an additional expansion of the load in a separate cylinder. Such engines were already being constructed by the end of the $19^{\text {th }}$ century, and they were modelled on steam machines with a multipleexpansion process. At the time, such engines were called "compound engines" in English, "moteur compound" in French and "Verbundmotor" in German [35]. Nowadays, the term "five-stroke engine" is most commonly used to describe this type of engine; the term comes from the fifth stroke of additional charge expansion preceded by a classic four-stroke cycle. At the end of the $19^{\text {th }}$ and the beginning of the $20^{\text {th }}$ century, two-stage expansion engines were developed by several inventors, including Rudolf Diesel [45], but they did not gain much popularity due to problems with the correct implementation of the additional expansion process. These difficulties were mainly material based. The exhaust gas at the inlet to the additional expansion cylinder still had a high temperature. This forced a requirement to cool the valves of the inlet channels of these cylinders and this effectively reduced energy gains from the additional expansion process. The idea of building an engine with additional expansion of the charge returned at the end of the $20^{\text {th }}$ and beginning of the $21^{\text {st }}$ century in the era of the dynamic development of materials, technologies and construction methods used in automotive engineering. The decisive factor here was the specific feature of the fivestroke engine in which the fired cylinder can have optimum parameters due to high specific power, while the use of an additional expansion process in a separate cylinder enables the engine to achieve a higher level of thermal efficiency. Currently, five-stroke engines are being developed in several research and development facilities $[2,28]$. Due to the specific features of these engines, they are suitable for the purpose of driving an on board or a stationary electric generator. Various engine arrangements of this type are known. The most popular is the system with two fired cylinders (high-pressure) and with one additional expansion (lowpressure) cylinder located between them. The fired cylinders work in a four-stroke cycle, with the working phase shifted by $360^{\circ} \mathrm{CA}$ and alternately supply exhaust gases to the central low-pressure cylinder operating in a two-stroke mode. This means the full use of both fired cylinders as well as an additional expansion cylinder. 


\section{Brief description of the engine and the motivation for aftertreatment development}

The four-cylinder in-line spark-ignition engine, in which two inner cylinders serve as a common volume of additional expansion of exhaust gases coming from the outer fired cylinders, was designed and built at Cracow University of Technology in 2011-2013 as part of the project No. N N509 559040 [41]. The engine design was based on an existing four-cylinder four-stroke engine. The change in the nature of the work from four-stroke to five-stroke was mainly based on the extensive modification of a cylinder head, camshafts, intake, exhaust systems, and charging system. The scheme of the modified cylinder head of an engine developed at Cracow University of Technology is presented in Fig. 2 .

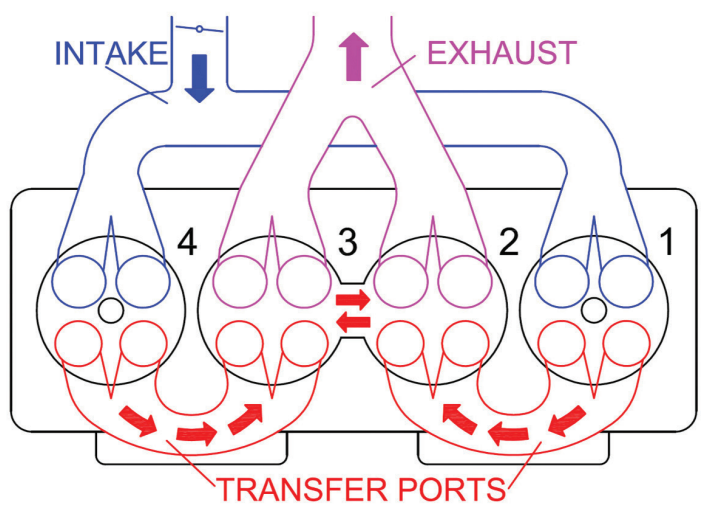

Fig. 2. Scheme of the modified cylinder head of a five-stroke engine designed at Cracow University of Technology

In the engine presented in Fig. 2, a classic four-stroke cycle is implemented in cylinders 1 and 4. The shift of the working phase between these cylinders referred to as fired or high-pressure (HP) is $360^{\circ} \mathrm{CA}$. Low-pressure cylinders (LP) nos. 2 and 3 have been connected by a port made in the cylinder head and have one common volume to which the combustion gases from cylinders 1 and 4 are alternately provided for additional expansion. Only after the additional expansion to a volume twice as large as the volume of the medium at the beginning of the compression stroke in cylinder 1 and 4 , does the exhaust gas leave the engine through the four exhaust valves of cylinders 2 and 3 simultaneously. In order to efficiently use the features of the engine with a two-stage expansion process, a turbocharging system was applied. In brief, the use of the process of additional expansion of exhaust gases is the more beneficial, the higher the temperature and pressure at the end of the main expansion process are. With a properly conducted combustion of the stoichiometric mixture these will depend on the amount of charge delivered to the cylinder $[36,37]$. In practice, the restriction is the increase in the exhaust gas pressure upstream from the turbine resulting from the increase of the required boost pressure. The increase in exhaust backpressure leads to the limitation of the positive effects of the additional expansion process; therefore, the dependence of the thermal efficiency of the five-stroke engine on the load has 
a local maximum. Depending on the rotational speed, maximum efficiency was obtained at the boost pressure within the range 0.2 to 0.65 bar [34]. In Fig. 3, the theoretical pressure courses in the fired cylinders (red) and in the internally connected additional expansion cylinders (blue) are presented. The figure shows the pressure drop between the end point of the power stroke in the fired cylinder and the beginning of the additional expansion process - the red line passing into the blue line. This results from the undesirable expansion of gases in the volume of the port connecting the cylinders and in the chambers above the pistons (previously being the combustion chambers) of the additional expansion cylinders. In the case of this engine, these volumes should be treated as undesirable (as is the case with the clearance volume in the piston compressor); however, it was not possible to minimise them in the cylinder head built on the basis of the existing structure.

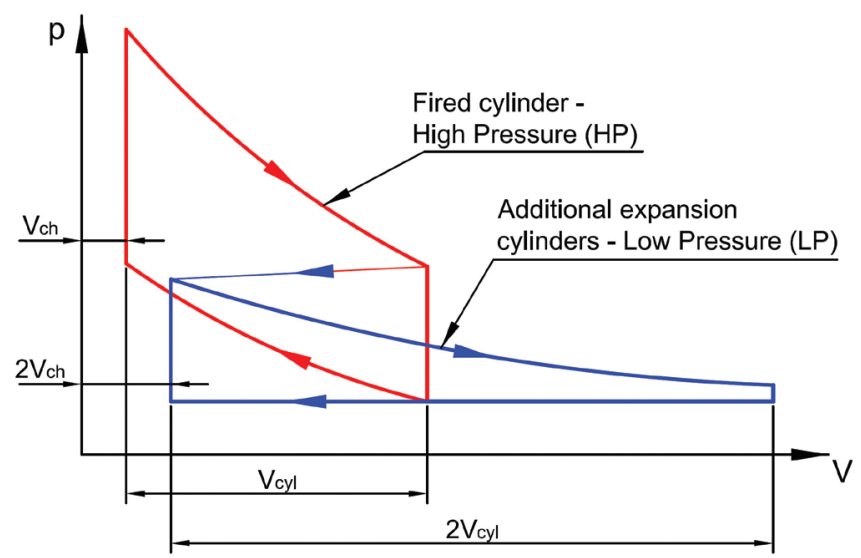

Fig. 3. The basic theoretical cycle of the fired cylinder (red line) and the cycle of additional expansion conducted in a separate cylinder (blue line)

The basic technical specifications of the engine with additional expansion of exhaust gases developed at Cracow University of Technology in its current configuration are shown in Table 1.

Table 1. Basic technical data of a five-stroke engine developed at Cracow University of Technology [34]

\begin{tabular}{|l|l|}
\hline \multicolumn{1}{|c|}{ Parameter } & \multicolumn{1}{c|}{ Value/Description } \\
\hline type and manufacturer of the base engine & Volkswagen EA113, 2.0 $\mathrm{dm}^{3} \mathrm{TFSI}, 147 \mathrm{~kW}$ \\
\hline no. of cylinders in 5-stroke arrangement & 2 fired / 2 for additional expansion \\
\hline displacement of fired cylinders, $\mathrm{dm}^{3}$ & $0.992($ both) \\
\hline displacement of add. exp. cyl., $\mathrm{dm}^{3}$ & $0.992($ both) \\
\hline bore, mm & 82.5 \\
\hline stroke, mm & 92.8 \\
\hline no. of valves & 4 per cylinder \\
\hline
\end{tabular}


Table 1 cont.

\begin{tabular}{|l|l|}
\hline \multicolumn{1}{|c|}{ Parameter } & \multicolumn{1}{c|}{ Value/Description } \\
\hline compression ratio, - & 10.5 \\
\hline overall expansion ratio, - & 21 \\
\hline fuel system & direct Injection \\
\hline injection pressure, MPa & 7 \\
\hline engine Management System & AEM EMS 30-1010 \\
\hline control of Air-Fuel Ratio & closed-loop, wideband $\mathrm{O}_{2}$ sensor \\
\hline injector driver & Denso 131000-1041 \\
\hline ignition system & individual coils \\
\hline fuel & petrol, RON 98 \\
\hline IVO/IVC fired cylinders & $7^{\circ}$ ATDC / 17 ${ }^{\circ}$ ABDC \\
\hline EVO/EVC fired cylinders & $28^{\circ}$ BBDC / $8^{\circ}$ BTDC \\
\hline IVO/IVC additional exp. cylinders & $28^{\circ}$ BTDC / $8^{\circ}$ BBDC \\
\hline EVO/EVC additional exp. cylinders & $28^{\circ}$ BBDC / $8^{\circ}$ BTDC \\
\hline turbocharger model & BV35-54359710015 \\
\hline boost pressure control method & variable geometry of turbine nozzle \\
\hline
\end{tabular}

The engine developed at Cracow University of Technology was the subject of several previous studies [34-37] and [39-41]. These works focused mainly on aspects related to the description of the design itself in which the engine was constructed on the basis of an existing four-stroke engine, issues of the thermodynamic description of processes occurring in it and the analysis of engine test results in the context of its thermal and mechanical efficiency indicated the mean effective pressure and the ratio of exhaust energy recovery in cylinders of additional expansion.

Until now, relatively little space has been devoted to issues related to the toxicity of exhaust gas. Some preliminary results of experimental research in this matter are presented in previous research [40]. These results concerned the raw exhaust emissions because until now, the engine was not equipped with an exhaust-gas aftertreatment system. Only a little information is available on the subject of exhaust toxicity of a similar engine developed from scratch and tested by the Keromnes, Schmitz et al. team [24]. However, nowadays issues related to emissions from propulsion sources are at the forefront, not only in the automotive industry but also in other transport areas as well as in the energy sector. For this reason, the next, natural stage of development of the design had to be the development of the aftertreatment system because without such a system, the internal combustion engine, or a vehicle equipped with it, is not able to meet any modern emission standards. This paper is devoted to the presentation of the effects of current work in this matter. 


\section{Research problem and aim of work}

The design of the engine with the additional expansion of the exhaust in a separate cylinder is oriented to the maximum use of the energy of the burned fuel. The use of additional expansion of exhaust gases in a separate working space causes the temperature of exhaust gases reaching the inlet of the turbine to be already relatively low, and at the turbine outlet, the temperature of the exhaust gases is even lower. Sample results obtained during the operation of the engine at a constant rotational speed of $2,000 \mathrm{rpm}$ and the opening of the throttle within the range of 7 to $100 \%$ are shown in Fig. 4. It should be noted here that the presented results were obtained in the previous configuration of the research engine, without a catalytic converter and when it was equipped with a turbocharger with a waste-gate valve, but this fact does not have a significant impact on the temperature measured downstream from the turbine.

$2000 \mathrm{rpm} ; \lambda=1.0$

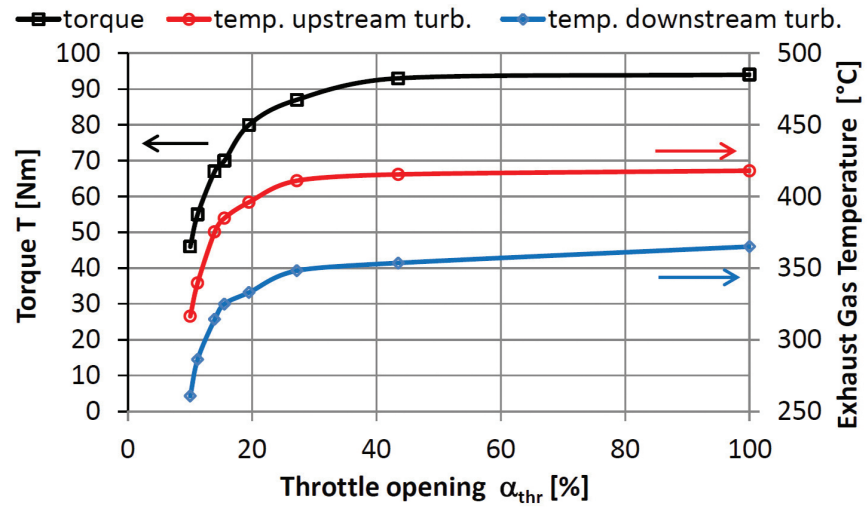

Fig. 4. Torque and exhaust gas temperature of the engine with additional expansion as a function of throttle opening

As can be seen above, in the range of a moderate load, below $60 \mathrm{Nm}$, the temperature of exhaust gases downstream from the turbine is slightly higher than $250^{\circ} \mathrm{C}$, which is considered to be the temperature of the beginning of the effective operation of an ordinary three-way catalytic converter [19]. However, the values presented in the chart were obtained after a certain time of engine operation with given parameters. In the period immediately after starting a cold engine, when (mainly for the sake of its durability) it works for some time without a load, and then with a low load, the temperature of the exhaust is even lower and the warming-up of the exhaust system components, including the catalytic converter, progresses slowly. During this period of operation of the five-stroke engine, the classic three-way catalyst would not work at all.

The aim of this work is to find a three-way catalytic converter, which, on the one hand, will allow a significant reduction in the concentration of toxic exhaust components starting from the lowest possible temperature of the exhaust downstream from the turbine, and on the other hand, will have low exhaust gas flow resistance. Increasing the flow resistance raises backpressure of gases in the exhaust system, which in turn increases the pumping losses, reducing the effect of energy recovery in the cylinders of the additional expansion of the five-stroke engine [27]. 


\section{Test stand}

Tests were performed on the engine test bench with an Eddy-current dyno. The measurement of fuel consumption was conducted by applying the mass method using the system integrated with the dyno controller. The exhaust gas composition measurements were performed with the use of a Capelec CAP 3201 class 0 analyser, which allows the measurement of the volume concentration of the most important components of dry exhaust gases, such as carbon dioxide, carbon monoxide, oxygen, nitrogen oxides and hydrocarbons converted to hexane. $\mathrm{CO}_{2}, \mathrm{CO}$ and $\mathrm{HC}$ are measured using the NDIR method, while electrochemical cells are used to determine $\mathrm{O}_{2}$ and $\mathrm{NO}_{x}$ concentrations. On the basis of the current exhaust gas composition, the analyser also calculates the value of relative air-fuel ratio $\lambda$. For this purpose, the Brettschneider formula is used [5].

Fig. 5 shows a view of the exhaust system of the engine with the additional expansion of exhaust gas with an installed catalytic converter.

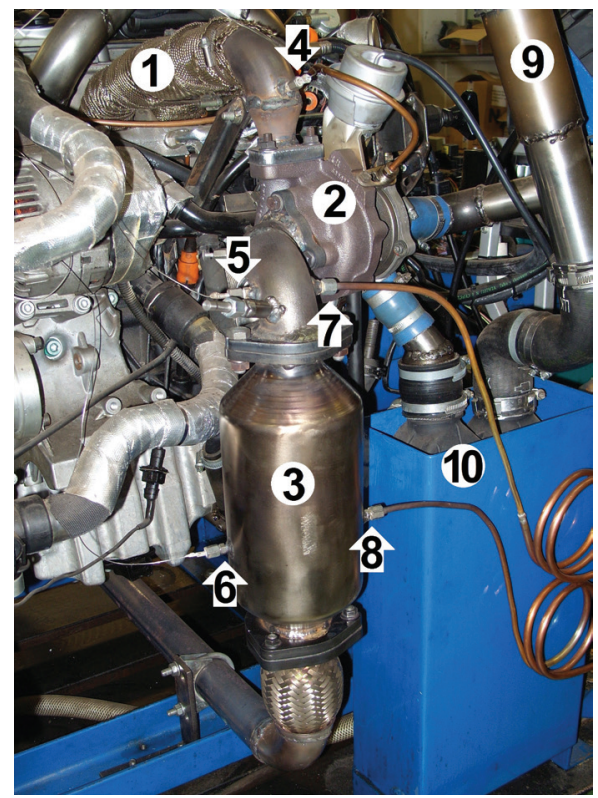

Fig. 5. Modified exhaust system of a five-stroke engine with a catalytic converter; 1 - engine exhaust manifold, 2 - turbocharger, 3 - catalytic converter, 4 - exhaust gas temperature measurement point upstream from the turbine, 5 - exhaust gas temperature measurement point upstream from the catalytic converter, 6 - exhaust gas temperature measurement point downstream from the TWC, 7 - exhaust gas sampling point for the analyser upstream from the catalytic converter, 8 - the sampling point downstream from the reactor, 9 - intake air pipes, 10 - charge air cooler

The catalytic converter was installed as close as possible to the turbine outlet so as to minimise heat losses to the ambient environment, which would delay the light-off of the aftertreatment system. The pipe connecting the turbine outlet to the inlet of the reactor is approximately $170 \mathrm{~mm}$ long. In order to estimate the conditions and effects of the catalytic 
converter operation, exhaust gas temperature values at selected points were measured using K-type thermocouples. Measurements were made at the following points of exhaust system:

1. In the port between the fired cylinder no. 1 and the cylinder of additional expansion no. 2;

2. In the engine exhaust manifold just upstream from the turbine inlet;

3. Upstream from the catalytic converter (downstream from the turbine);

4. Downstream from the catalytic converter outlet (close to the support).

One analyser was used for the tests, thus the measurement of the composition of the exhaust gas upstream and downstream from the catalytic converter required use of a valve enabling the switching of the gas-sampling point. Exhaust gases were sampled very close to the inlet of the catalytic converter and just after its outlet (directly after the reactor's support).

\section{Three-way catalytic converters used in the research}

Two catalytic converters were chosen for the research. One of these was built based on a metal support, while the other was based on a ceramic support. The displacement volume of the test engine is $0.992 \mathrm{dm}^{3}$. The operation of the engine with the boost pressure not exceeding 0.5 bar and the rotational speed below $4,000 \mathrm{rpm}$ is foreseen, as well as with the stoichiometric air-fuel mixture. The result is that the maximum torque achieved by the engine is limited to approximately $130 \mathrm{Nm}$, which in effect gives a maximum power level below $55 \mathrm{~kW}$. Based on these estimates, a ceramic catalytic converter from a passenger car with a naturally aspirated engine with a displacement volume of $1.2 \mathrm{dm}^{3}$ and a maximum power of $59 \mathrm{~kW}$ at $6,000 \mathrm{rpm}$ was selected. The second converter, with a metal support, is for universal application and is designed for engines with a displacement volume of 1.3 to $1.6 \mathrm{dm}^{3}$. The basic dimensions and technical data of catalytic converters are shown in a Table 2.

Table 2. Basic technical data of converters used for research

\begin{tabular}{|c|c|c|}
\hline Parameter & Ceramic support converter & Metal support converter \\
\hline support cross section shape & round & round \\
\hline support diameter, $\mathrm{mm}$ & 110 & 86 \\
\hline support length, mm & 50 & 90 \\
\hline inlet/outlet inner diameter, $\mathrm{mm}$ & $48 / 48$ & $48 / 48$ \\
\hline total length, mm & 277 & 277 \\
\hline cell density, cpsi & 576 & 200 \\
\hline area of application & $\begin{array}{l}\text { underfloor converter (2nd of two) } \\
\text { from the B-segment car, }\end{array}$ & universal converter, \\
\hline engine displacement volume, $\mathrm{dm}^{3}$ & 1.2 , naturally aspirated & $1.3-1.6$, if naturally aspirated \\
\hline $\begin{array}{l}\text { exhaust emission standard of vehicle for } \\
\text { which converter is intended }\end{array}$ & Euro 6 & Euro 4 \\
\hline
\end{tabular}


Both catalytic converters used were brand new. In the case of the metal converter, the adaptation for use in a five-stroke engine was to weld the flanges to the inlet and outlet pipes. In the case of a ceramic support converter, the fixing of the necessary flanges had to be preceded by the removal of the original inlet and outlet pipes and the welding of straight pipe fragments, because the used converter was part of a larger element of the exhaust which is installed under the floor of the vehicle. A general view of the selected reactors after adaptation to the test bench of the five-stroke engine is presented in Fig. 6 .

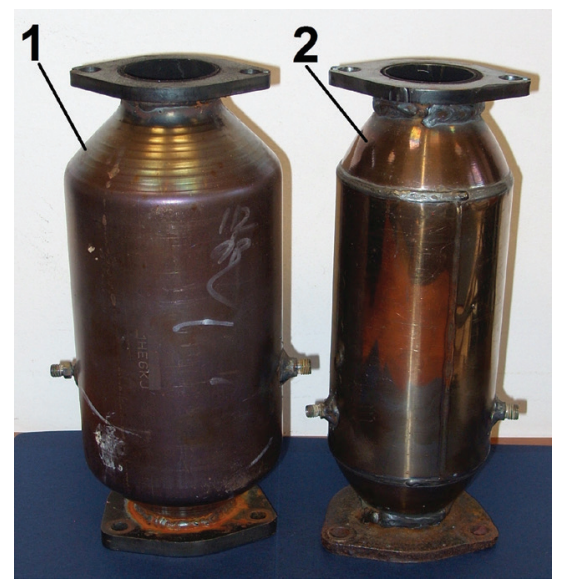

Fig. 6. Three-way catalytic converters tested with the five-stroke engine; 1 - Converter with a ceramic support, 2 - Converter with a metal support

As is visible in the picture above, both reactors below the support have attached connectors for thermocouple mounting (left hand side) and for the sampling of the exhaust after the catalyst for the analyser (right hand side). Unfortunately, no further information on the wall thickness, coatings and precious metal content was available for either catalytic reactor.

\section{Experimental research of the five stroke engine}

\subsection{Tests with the ceramic support three-way converter}

In the first part of the research, a catalytic converter with a ceramic support was used. The tests were performed at a low rotational speed of 2,000 rpm because in such a situation, the exhaust gas has a low temperature, thus creating beneficial conditions for verification of the aftertreatment system. The first measurements concerned the operation of the catalytic converter depending on the engine load with the assumed constant value of relative air-fuel ratio equal to 1.0. In each of the following measurement points, the engine was operated until the exhaust gas temperature measured downstream from the catalytic converter had stabilised. Fig. 7 presents the conditions for conducting tests. The graph shows the throttle opening and the ignition timing dependent on the load of the test engine. 


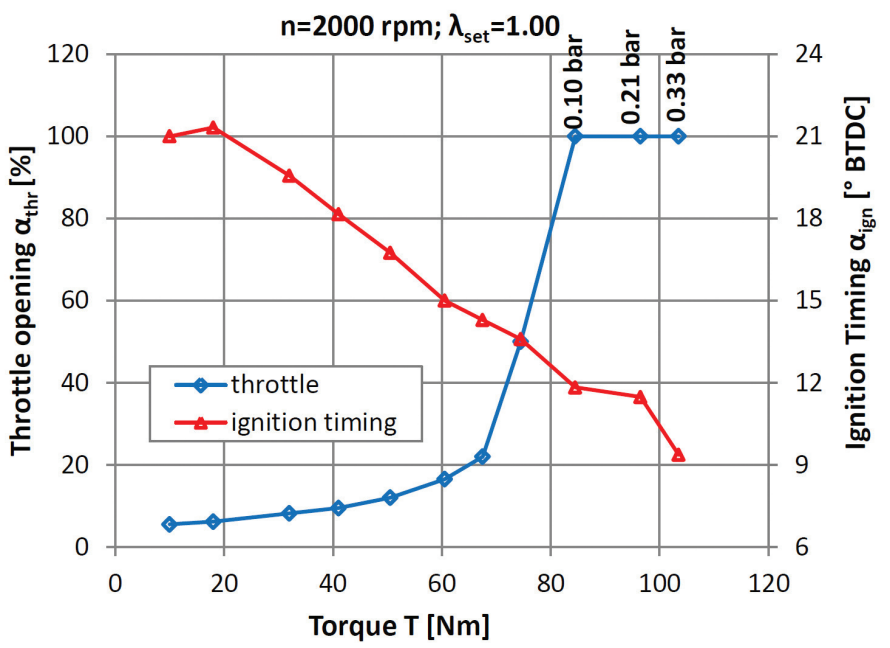

Fig. 7. Conditions for conducting tests depending on the load of the five-stroke engine

For each measurement point, the ignition timing was set so that the maximum torque was obtained for the determined throttle opening. The last three measuring points (from the right) were realised during operation of the engine with a wide-open throttle. Figures given at the points representing $100 \%$ throttle opening indicate the values of the boost pressure. The increase of the boost pressure was performed by changing the position of the turbine nozzles, which remained fully open up to the load of $84.5 \mathrm{Nm}$.

Fig. 8. presents the plots of exhaust gas temperature measured upstream and downstream from the catalytic converter dependent upon the load of the five-stroke engine. The graph also shows the course of the actual value of the relative air-fuel ratio measured by the exhaust gas analyser.

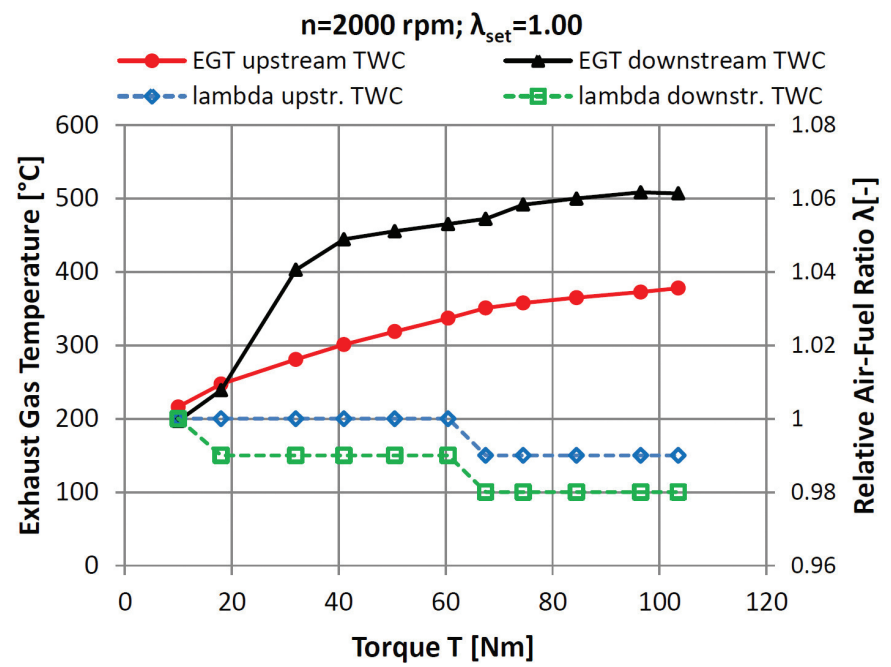

Fig. 8. Exhaust gas temperature upstream and downstream the catalytic converter with a ceramic support and the measured value of the relative air-fuel ratio depending on the engine load 
For the first two operating points (from the left), the exhaust gas temperature measured downstream from the converter is slightly lower than upstream from the TWC. This means that in the low load range, when the temperature of the exhaust gas measured upstream from the converter does not exceed $250^{\circ} \mathrm{C}$, TWC does not show any effect of activity. After exceeding the load of $20 \mathrm{Nm}$, exhaust gas temperature measured in the reactor inlet increased above $250^{\circ} \mathrm{C}$ and the converter started operating. This is characterised by the increase in the exhaust gas temperature measured below the catalytic reactor of $130^{\circ} \mathrm{C}$ in relation to the temperature at its inlet, which is the result of the exothermic character of reactions taking place inside the converter. The value of the relative air-fuel ratio measured on the basis of the composition of the exhaust shows a certain deviation in the direction of enrichment at a higher engine load. This is due to imperfections in the operation of the mixture composition control system in the closed loop. The error of adjusting the relative air-fuel ratio is 0.01 , which can be considered to be a relatively low value.

Fig. 9 shows the courses of volume concentrations of carbon monoxide and carbon dioxide in the exhaust gas of a five-stroke engine depending on its load. Continuous lines connect the results of measurements downstream from the catalytic converter, while the dashed lines refer to results upstream from TWC (note that these line styles also apply to the presentation of results later in this paper).

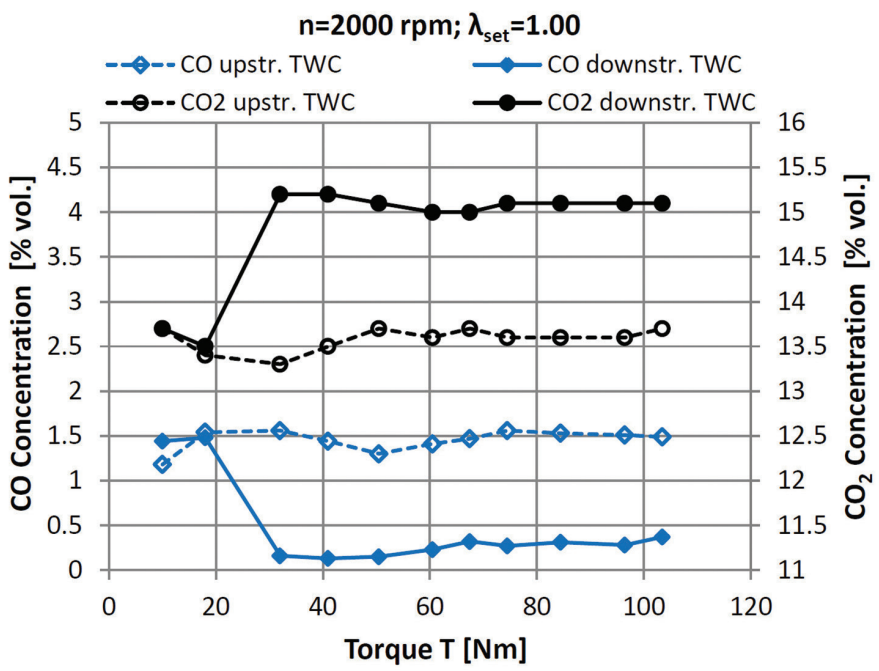

Fig. 9. Volume concentration of $\mathrm{CO}$ and $\mathrm{CO}_{2}$ in the exhaust gas of the five-stroke engine co-operating with a catalytic converter with a ceramic support as a function of the engine load

The previously presented results concerning the measurement of the exhaust gas temperature are also reflected in the course of exhaust gas composition changes measured downstream from the catalytic converter. At a load higher than $20 \mathrm{Nm}$, when the TWC has reached the temperature necessary for efficient operation, oxidation reactions of combustible components occur on reactor active surface as does the reduction of nitrogen oxide. This fact is reflected by an increase in the volume concentration of $\mathrm{CO}_{2}$ measured downstream 
from the catalytic converter by about $1.5 \%$ in relation to the measurement upstream from the TWC. In an analogous comparison, the volume concentration of CO drops by more than $1 \%$, reaching a value not exceeding $0.35 \%$ downstream from the catalytic converter.

Fig. 10 shows further results regarding the composition of exhaust gases as a function of the load of the engine cooperating with the ceramic-support converter. The figure shows the course of changes in the volume concentration of hydrocarbons and nitrogen oxides in the exhaust gases.

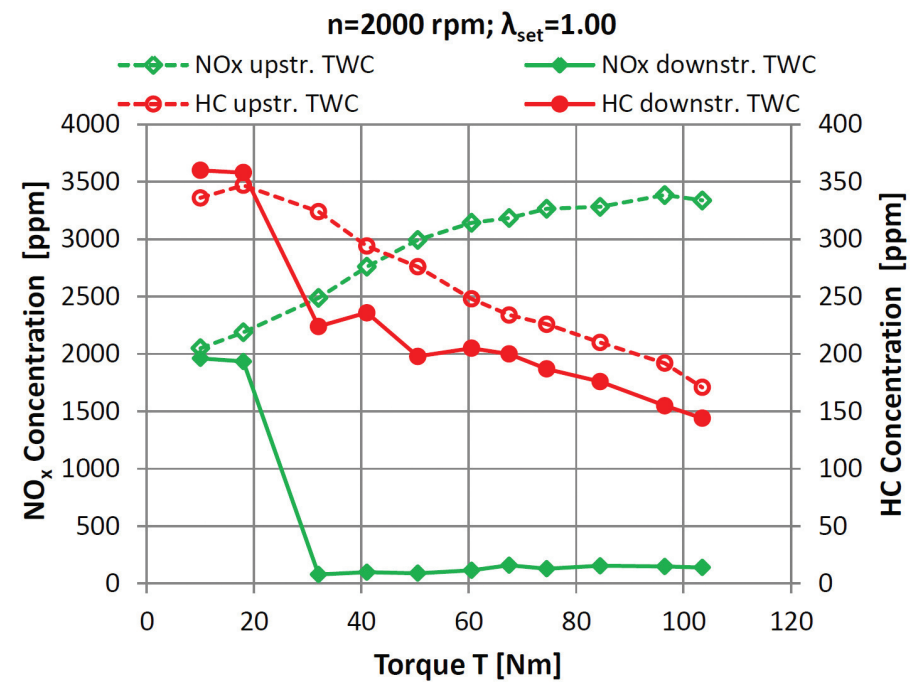

Fig. 10. Volume concentration of hydrocarbons and nitrogen oxides in the exhaust gases dependent upon the load of the five-stroke engine

In the region of the lowest engine load, below $20 \mathrm{Nm}$, the catalytic converter showed no activity. For the load higher than $20 \mathrm{Nm}$, a clear reduction in the volume concentration of nitrogen oxides downstream the catalytic converter was recorded. The $\mathrm{NO}_{\mathrm{x}}$ concentration values downstream from the catalytic converter change with loads higher than $20 \mathrm{Nm}$ from 80 to $160 \mathrm{ppm}$. The reduction in the volume concentration of unburned hydrocarbons in the catalytic converter has a much smaller intensity. The difference in the volume concentration of $\mathrm{HC}$ upstream and downstream from the TWC varies from $100 \mathrm{ppm}$ at a load of $32 \mathrm{Nm}$, which is about $30 \%$ of the initial value, to only $27 \mathrm{ppm}$ at the maximum load, which in this test is $103.5 \mathrm{Nm}$. The HC reduction is then only slightly above $15 \%$ of the initial value. The singularity consisting in registering the increase in the volume concentration of $\mathrm{HC}$ downstream from the catalytic converter, when it does not show normal activity, results from the NDIR measurement method used in the analyser used for the tests. A certain change in the composition of the exhaust gas occurring in a reactor functioning below light-off temperature, but heated to over $200^{\circ} \mathrm{C}$ results in an increase in the absorption of infrared radiation of a specific wavelength for hexane. As a result, this leads to an overestimation of the measurement of the volume concentration of hydrocarbons in the exhaust gas leaving the catalytic converter. A more accurate recognition of the mechanism of this phenomenon would require additional studies and research; this was not the subject of this study. 
Fig. 11 shows plots of the conversion efficiency of a catalytic converter with a ceramic support as a function of the load of the engine with the additional expansion of exhaust gases.

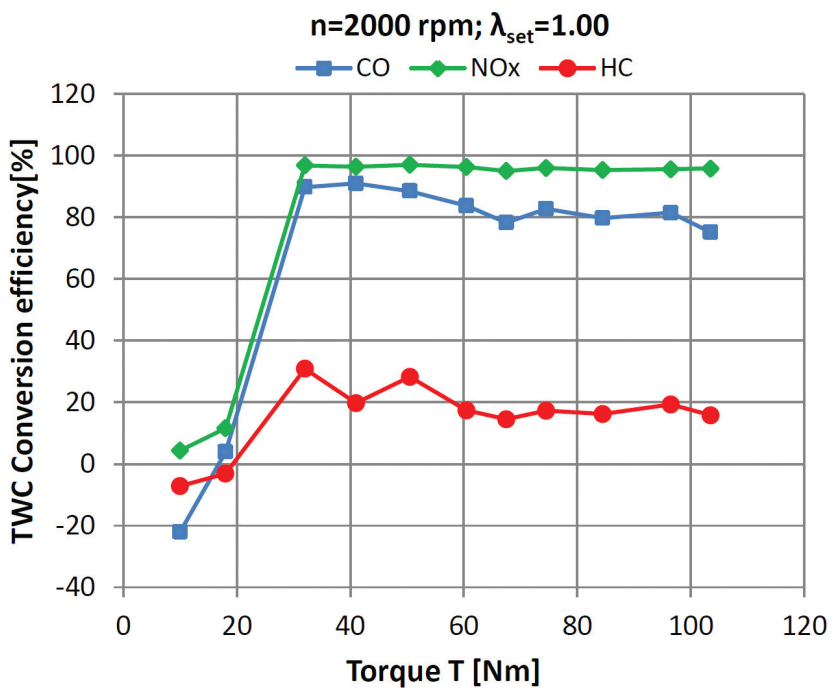

Fig. 11. Graphs of conversion efficiency of TWC with a ceramic support as a function of load of the engine with the additional expansion of exhaust gases

During the test, the highest values of the conversion efficiency of toxic exhaust components in the TWC were obtained for nitrogen oxides. In the load range in which the reactor was active, the $\mathrm{NO}_{\mathrm{x}}$ conversion efficiency values exceeded 95\%. Slightly lower conversion efficiency of the reactor was achieved for the oxidation of carbon monoxide. The conversion efficiency for carbon monoxide was about $90 \%$ at $32 \mathrm{Nm}$ and showed a decreasing trend when the engine load increased. For a load of $103.5 \mathrm{Nm}$, the conversion efficiency with respect to the volume concentration of carbon monoxide was about $75 \%$. In the conditions of the tests, the applied catalytic converter was by far the least efficient at dealing with the neutralisation of unburned hydrocarbons. The conversion efficiency of the TWC for this group of compounds at medium and high loads oscillated at around 20\%. Slightly higher values, around 30\%, were recorded when the engine operated with a partial load between 32 and $50 \mathrm{Nm}$.

In the next part of the work, a cooperation of the five-stroke engine with a catalytic converter with a ceramic support as a function of air-fuel mixture composition at partial engine load was investigated. A constant rotational speed of 2,000 rpm, a throttle opening of $15 \%$ and an ignition timing of $16^{\circ} \mathrm{CA} \mathrm{BTDC}$ were set. Figure 12 shows the course of torque and brake specific fuel consumption of the five-stroke engine co-operating with a catalytic converter with a ceramic support depending on the composition of the air-fuel mixture.

A maximum torque of $63 \mathrm{Nm}$ was obtained when the engine was fed with a mixture of $\lambda=0.87$. The minimum value of the specific fuel consumption was $282 \mathrm{~g} / \mathrm{kWh}$ and was obtained for a mixture with a composition of $\lambda=1.10$. The values of the relative air-fuel ratio at which the maximum torque and the minimum specific fuel consumption were recorded do not differ from those obtained in the case of conventional four-stroke spark-ignition engines. 


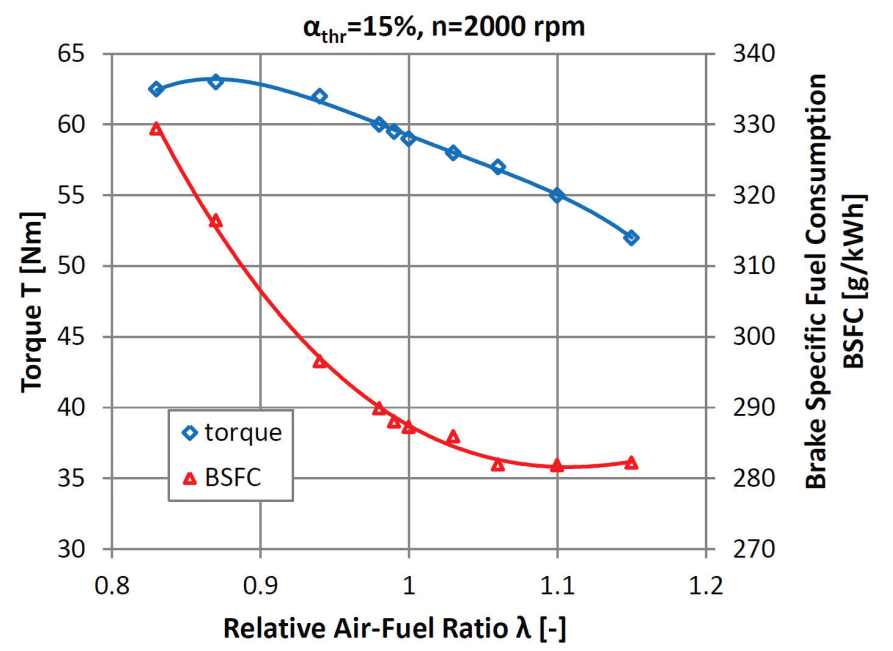

Fig. 12. Graphs of torque and brake specific fuel consumption of the five-stroke engine co-operating with the TWC with a ceramic support depending on the composition of the air-fuel mixture

Fig. 13 shows the dependence of exhaust gas temperature on the mixture composition. As before, the temperature of the exhaust gas upstream and downstream from the catalytic converter was recorded. Also recorded was the temperature upstream from the inlet of the turbine and in the port connecting the fired cylinder no. 1 with the cylinder of the additional expansion no. 2.

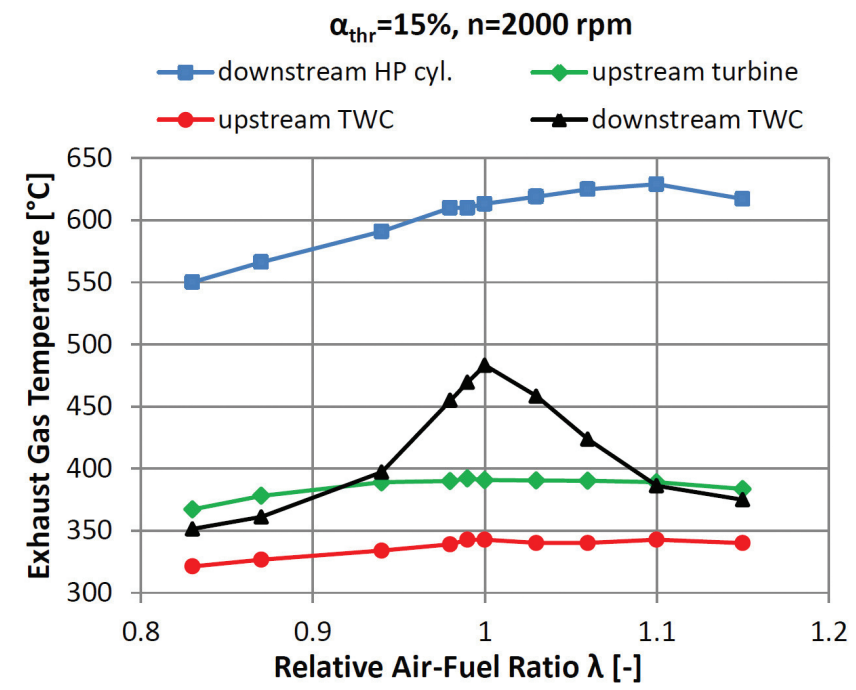

Fig. 13. Exhaust gas temperature of the five-stroke engine co-operating with the TWC with a ceramic support depending on the air-fuel mixture composition

The maximum value of the temperature in the port between the HP and LP cylinders $\left(629^{\circ} \mathrm{C}\right)$ was recorded for the value of the relative air-fuel ratio 1.10 . This temperature is higher than that registered for the stoichiometric mixture by $16^{\circ} \mathrm{C}$. This is the result of 
reducing the heat release rate and shifting the combustion process to the further part of the power stroke in the case of feeding the engine with a lean mixture. The decrease of the exhaust gas temperature measured upstream from the additional expansion cylinder and in the engine exhaust manifold upstream from the turbine inlet has values in the range from 180 to $240^{\circ} \mathrm{C}$; the higher the exhaust gas temperature measured in the port in the inlet of additional expansion cylinder was, the higher this decrease was. This is due to the fact that, firstly, the process of additional expansion brings a stronger effect in the form of work transferred to the crankshaft, and secondly, the increase in the temperature of exhaust gases is associated with the intensification of the heat transfer process to the cylinder and exhaust manifold walls. The temperature drop between the inlet and outlet of the turbine assumes an approximately constant value of around $50^{\circ} \mathrm{C}$. This is the result of the operation of the engine in the part load range when the turbine operated without load; therefore, the temperature drop is the result of heat exchange with the walls of its housing more than an expansion in the turbine. The exhaust gas temperature measured downstream from the catalytic converter had a higher value at each measurement point than that measured upstream from the converter. This gives rise for asserting that the catalytic converter at each of the measurement points at least partially fulfilled its basic function. The highest temperature increase of $140^{\circ} \mathrm{C}$ was recorded with a relative air-fuel mixture of 1.0 , which was to be expected for a three-way catalytic converter. This is the result of the most efficient operation of the reactor, when the engine works with the mixture of an exactly stoichiometric composition.

Fig. 14 shows plots of the volume concentrations of carbon monoxide and carbon dioxide in the exhaust gas of a five-stroke engine as a function of the air-fuel mixture composition.

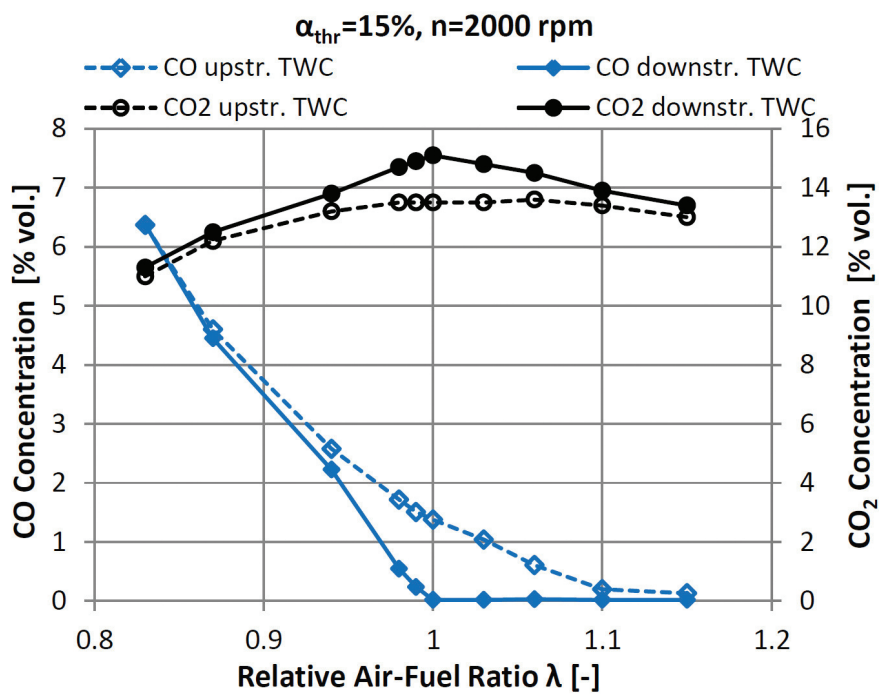

Fig. 14. Graphs of the volume concentrations of carbon monoxide and carbon dioxide in the exhaust gas of a five-stroke engine as a function of the air-fuel mixture composition 
The highest reduction in the volume concentration of carbon monoxide in the catalytic converter was obtained when the engine was fed with a stoichiometric mixture. The volume concentration of $\mathrm{CO}$ was reduced from $1.38 \%$ to $0.02 \%$. This is accompanied by an increase in the volume fraction of $\mathrm{CO}_{2}$ in the exhaust downstream from the catalytic converter to $15.1 \%$, while the concentration of $\mathrm{CO}_{2}$ upstream from the converter was $13.5 \%$. The ceramic support catalytic converter coped well with $\mathrm{CO}$ oxidation to $\mathrm{CO}_{2}$ when the engine was powered by a lean mixture. The volume concentration of $\mathrm{CO}$ downstream from the TWC had a constant value of $0.02 \%$. When the mixture was enriched more than the stoichiometric composition, the reduction of the volume concentration of $\mathrm{CO}$ in the catalytic converter decreased in value until the reactor no longer oxidised $\mathrm{CO}$ to $\mathrm{CO}_{2}$ and the carbon monoxide concentration measured upstream and downstream from the converter were the same. It occurred when the engine was operating using the mixture of the relative air-fuel ratio of 0.87 .

Fig. 15 presents graphs of the volumetric concentration of hydrocarbons and nitrogen oxides in the exhaust gas of a five-stroke engine cooperating with the ceramic support TWC depending on the composition of the air-fuel mixture.

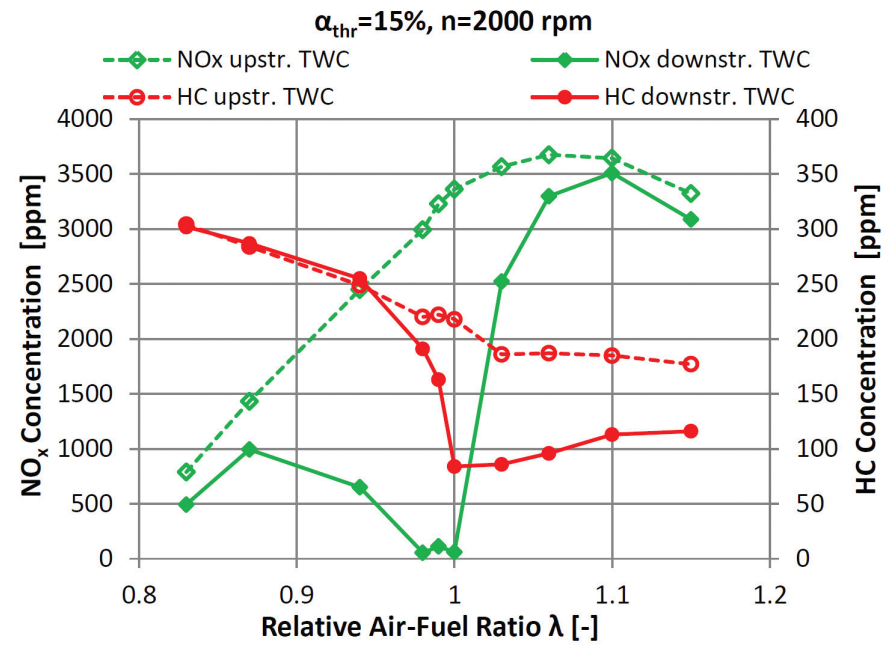

Fig. 15. Plots of the volumetric concentration of hydrocarbons and nitrogen oxides in the exhaust gas depending on the composition of the air-fuel mixture

The plot of the volume concentration of nitrogen oxides is as usually observed, with the maximum achieved for a mixture with a slightly leaner composition than the stoichiometric$\lambda=1.06$. The most beneficial results in the reduction of the volume concentration of $\mathrm{NO}_{\mathrm{x}}$ were recorded when feeding the engine with a mixture from slightly enriched up to stoichiometric composition $-\lambda$ from 0.98 to 1.00 . The concentration of $\mathrm{NO}_{\mathrm{x}}$ in the exhaust gases was reduced from over 3,000 ppm to below $100 \mathrm{ppm}$. The plot of changes in the volume concentration of hydrocarbons is approximately linearly descending when the relative air-fuel ratio grows. The maximum value of the $\mathrm{HC}$ volume concentration was recorded for the value of the relative air-fuel ratio equal to 0.87 . As in the case of carbon monoxide, hydrocarbons at this point in the catalytic converter showed no activity. Oxidation of unburned hydrocarbons in the 
converter only occurred when the five-stroke engine was fed by a mixture with a composition close to stoichiometric. The maximum reduction in the volume concentration of $\mathrm{HC}$ in the catalytic converter was recorded for the mixture with a stoichiometric composition. The volume concentration of hydrocarbons upstream from the catalytic converter was $218 \mathrm{ppm}$, while the measurement result downstream from the converter was only $84 \mathrm{ppm}$.

The plots of efficiency of conversion of the catalytic converter with the ceramic support as a function of the relative air-fuel ratio of the mixture are presented in Fig. 16.

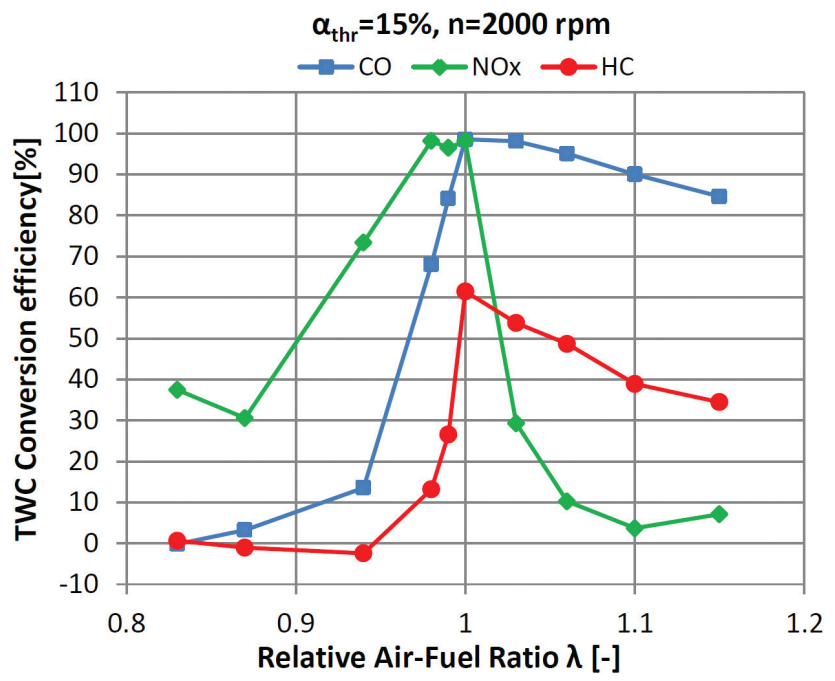

Fig. 16. Diagrams of conversion efficiency of the catalytic converter with the ceramic support as a function of the relative air-fuel ratio of the mixture

The maximum overall conversion efficiency of a catalytic reactor with a ceramic support was obtained when the engine was fed with a mixture of a stoichiometric composition. In the case of carbon monoxide and nitrogen oxides, conversion efficiency levels of $98.5 \%$ and $98.2 \%$ respectively were obtained. The efficiency of hydrocarbon conversion was considerably lower for the mixture with a stoichiometric composition $-61.5 \%$. However, it should be noted that this was the highest of the obtained HC conversion efficiency values registered during the research that is the subject of this study. The catalytic reactor obtained an acceptably high efficiency of nitrogen oxide conversion when the engine was fed with a mixture with a relative air-fuel ratio of 0.98 to 1.00 ; for carbon monoxide, this value of $\lambda$ was in the range of 1.00 to 1.03. In the case of hydrocarbons, a change of the mixture composition from the stoichiometric composition caused a significant decrease in the conversion efficiency of the catalytic converter from the aforementioned value of $61.5 \%$.

In the last part of the research on the ceramic-support TWC conducted under quasistationary conditions, measurements were made of the influence of ignition timing on the exhaust temperature of the engine with the additional expansion process. The tests were primarily aimed at determining the range of the increase in the exhaust gas temperature measured upstream from the catalytic converter with the ignition retarded from the point 
allowing the obtaining of the maximum torque for a given operating point. Increasing the exhaust gas temperature would shorten the time taken for the converter to warm up to activation temperature. During this part of the research, it was also determined what the cost of such an operation would be in the form of an increase in the specific fuel consumption. The tests were performed at a rotational speed of 2,000 rpm and with a partial throttle opening of $15 \%$, with the stoichiometric mixture feeding. These conditions allowed obtaining the maximum brake torque (MBT) at this operating point of $60.5 \mathrm{Nm}$ for an ignition timing of $17.1^{\circ} \mathrm{CA}$ BTDC. Figure 17 presents graphs of the exhaust gas temperature of a five-stroke engine depending on the ignition timing.

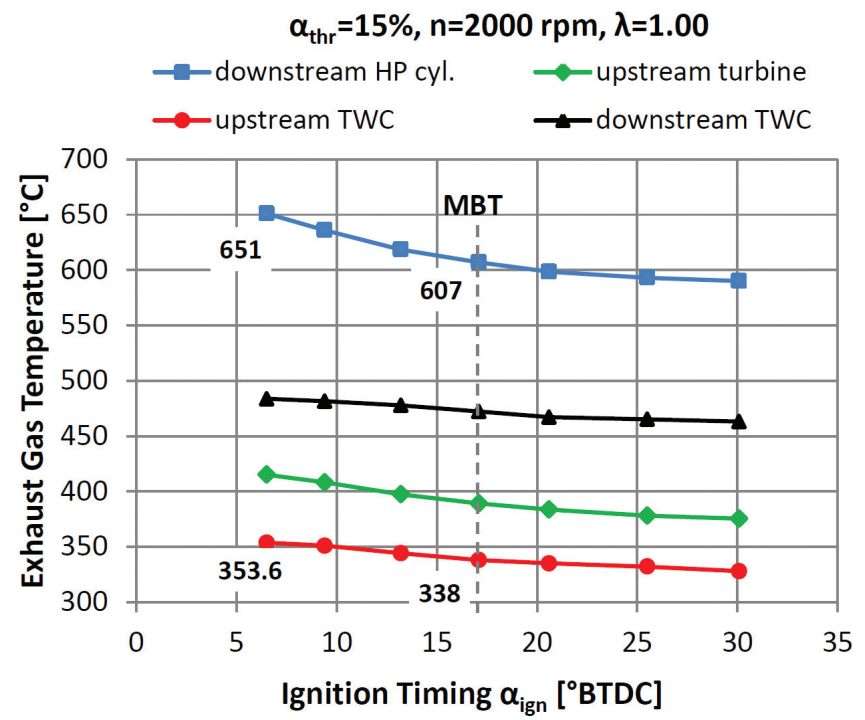

Fig. 17. Exhaust gas temperature of the five-stroke engine as a function of the ignition timing

Retarding of the ignition by $10.6^{\circ} \mathrm{CA}$ from the MBT point results in an increase of $44^{\circ} \mathrm{C}$ (from 607 to 651) in the exhaust gas temperature measured in the port between the fired cylinders and an additional expansion cylinder. An analogous comparison of the exhaust gas temperature measured upstream from the catalytic converter indicates that the temperature increased only by $15.6^{\circ} \mathrm{C}$ with the retarded ignition. A disproportionally low increase in the exhaust gas temperature measured upstream from the converter results from the intensified heat transfer in the additional expansion cylinders, the exhaust manifold of a relatively long length and the turbocharger. This is not a beneficial phenomenon because it hinders the use of what is basically the simplest method of accelerating the warming-up of a catalytic converter in order to shorten the period of its activation. Graphs of torque and brake specific fuel consumption of the five-stroke engine in the function of the ignition timing are shown in Fig. 18.

Shifting the ignition point from 17.1 to $6.5^{\circ} \mathrm{CA} \mathrm{BTDC}$ results in a reduction of the engine torque by $6.5 \mathrm{Nm}$, i.e. by more than $10.7 \%$. This corresponds to an increase in brake specific fuel consumption by $34 \mathrm{~g} / \mathrm{kWh}$ (this is a relative increase from the initial value by $12 \%$ ). 


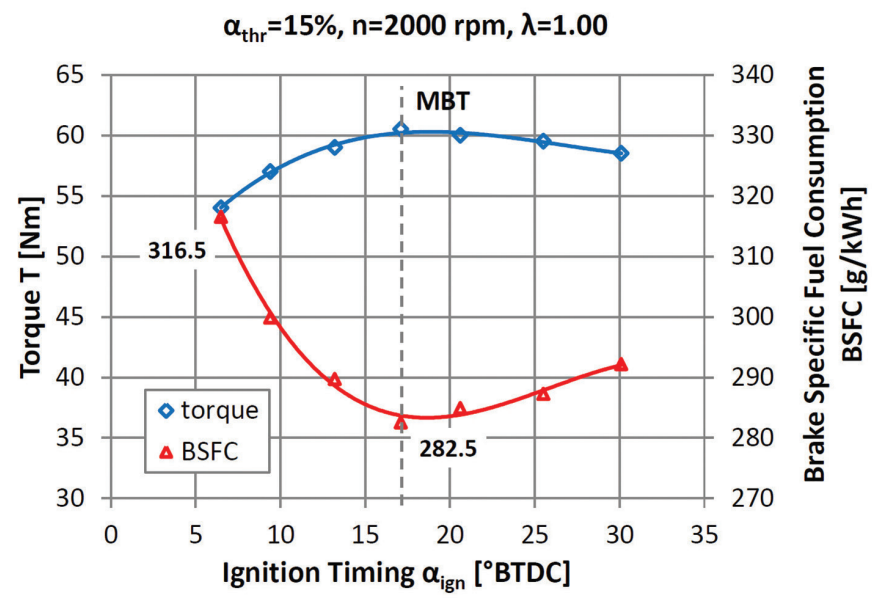

Fig. 18. Torque and brake specific fuel consumption of the five-stroke engine as a function of the ignition timing

During the tests with variable ignition timing, the composition of the exhaust gases upstream and downstream from the catalytic converter was also recorded. The nature of changes in the volume concentrations of analysed components was analogous to the results usually obtained in the case of a classic four-stroke engine. The highest sensitivity to changes in the ignition timing was of course related to the volume concentration of nitrogen oxides. For the ignition timing of $6.5^{\circ} \mathrm{CA} \mathrm{BTDC}$, the $\mathrm{NO}_{\mathrm{x}}$ concentration was $2,400 \mathrm{ppm}$, while for the ignition timing of $30.1^{\circ} \mathrm{CA}$ BTDC, it was as high as $4,300 \mathrm{ppm}$. The conversion efficiency of the catalytic converter maintained approximately constant levels independently of the ignition timing setting and was approx. $98 \%$ for $\mathrm{NO}_{\mathrm{x}}$, approx. $82 \%$ for CO and approx. $24 \%$ for HC.

\subsection{Tests with the metal-support three-way converter}

In the second phase of work on the development of the exhaust gas aftertreatment system for the five-stroke engine constructed at the Cracow University of Technology, a catalytic converter with a support made of a steel sheet was tested. The research was conducted in order to estimate the impact of the use of the reactor with lower flow resistance on the performance and efficiency of the test engine and to determine to what extent the reactor with the metal support would fulfil its fundamental task. The mentioned task is to limit the concentration of toxic components of engine exhaust. The reactor which was used had a support with a cell density of 200 cpsi made of a thin steel sheet. The assumption that the flow resistance through the catalytic converter would be lower than through a ceramic support reactor with a cell density of $576 \mathrm{cpsi}$ was therefore justified. However, the metal support of the reactor had a significantly smaller active surface compared to the previously tested catalytic converter with a ceramic support; therefore, there were concerns about the efficiency of the second 
converter in relatively difficult conditions caused by low exhaust gas temperature. During the tests of a five-stroke engine with a metal support catalytic converter, exactly the same conditions and settings of the engine management system were maintained, as was the case with the research on a ceramic-support reactor.

The graphs of exhaust gas temperature measured upstream and downstream from the converter with a metal support as a function of the engine load represented as torque is shown in Fig. 19. The test was performed at a rotational speed of 2,000 rpm.

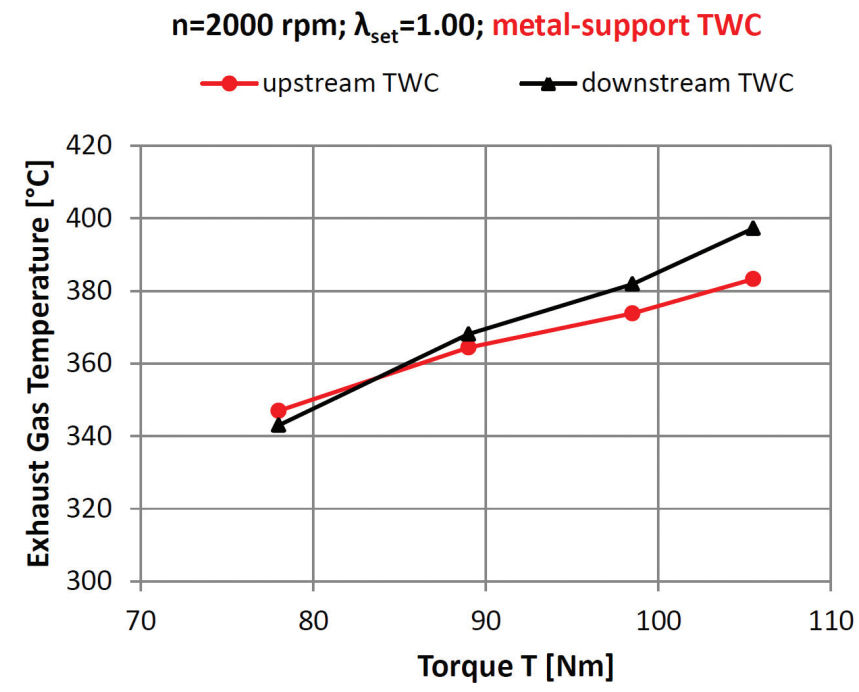

Fig. 19. Exhaust gas temperature measured upstream and downstream from the converter with a metal support as a function of the engine load at a rotational speed of $2,000 \mathrm{rpm}$

Due to the lack of any symptoms of the activity of the converter with a metal support at low and medium engine load, only the measurement results for the last four testing points were shown when the engine was operating at high load. In the first point of the chart the engine worked with a throttle opening of 50\%, and in the next three, the throttle opening was $100 \%$ and the boost pressure was adjusted as in the case of analogous tests of converter with a ceramic support (last three points from the right in Fig. 7). It is evident that in the first of the measurement points, the converter with a metal support did not show signs of active operation despite reaching an exhaust gas temperature of $347^{\circ} \mathrm{C}$ in the inlet. At a load higher than $85 \mathrm{Nm}$, the exhaust gas temperature measured downstream from the converter started to reach higher values than those upstream from the reactor. The recorded values of the temperature increase in the converter with a metal support, however, had very low values, from 4 to $14^{\circ} \mathrm{C}$, which indicates that the intensity of reactions in the converter was negligible. To confirm the last observation, the courses of volume concentration of carbon monoxide and carbon dioxide in exhaust gases of a five-stroke engine co-operating with the converter with metal support depending on the engine load are presented in Fig. 20. 
The $\mathrm{CO}$ and $\mathrm{CO}_{2}$ volumetric concentrations measured upstream and downstream from the catalytic converter had the same or very similar values regardless of the engine load. The difference in the volume concentration of $\mathrm{CO}$ measured at the last measurement point is only $0.09 \%$ ( $1.54 \% \mathrm{CO}$ downstream from the converter against $1.63 \% \mathrm{CO}$ upstream). This means that despite obtaining a temperature of around $400^{\circ} \mathrm{C}$, the tested catalytic converter with a metal support does not show any symptoms of efficient operation. The values of volume concentrations of $\mathrm{CO}_{2}$ before and after the catalytic reactor remain at the same level, which results from the resolution of the $\mathrm{CO}_{2}$ measurement in the used analyser $(0.1 \%)$. In fact, if a reduction in the carbon monoxide content was registered, there must have been some increase in the concentration of carbon dioxide measured downstream from the reactor. However, the change was so low that it did not change the analyser's indication.

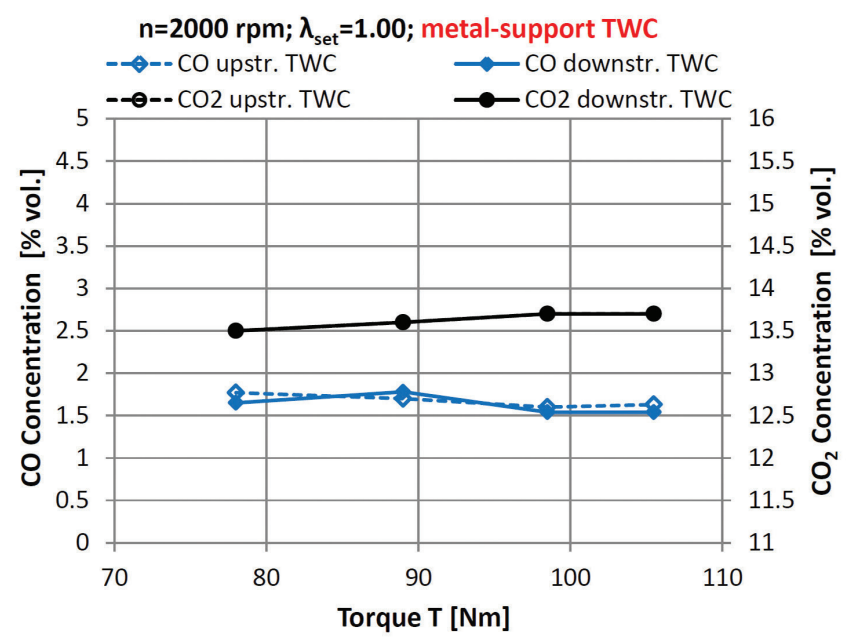

Fig. 20. Volume concentration of carbon monoxide and carbon dioxide in exhaust gases of a five-stroke engine co-operating with the converter with a metal support depending on the load

In order to verify whether the converter with a metal support will start operating at a higher exhaust gas temperature, the engine speed has been increased to 3,500 rpm. With a wide open throttle, a $17.1^{\circ} \mathrm{CA}$ BTDC ignition timing, a stoichiometric mixture composition and a boost pressure of $0.29 \mathrm{bar}$, the engine generated a torque of $107.5 \mathrm{Nm}$; this translates into an effective power value of $39.4 \mathrm{~kW}$. A bar chart of the conversion efficiency of the converter with a metal support obtained in this test is presented in Fig. 21.

Despite reaching an exhaust gas temperature of $478^{\circ} \mathrm{C}$ upstream from the converter, no acceptable conversion efficiency values were obtained. For $\mathrm{CO}, \mathrm{HC}$ and $\mathrm{NO}_{\mathrm{x}}$, these values were lower than $10 \%$. Ineffective converter operation also occurred at increased engine speed and high load is reflected in the exhaust gas temperature recorded downstream from the converter; this was $504^{\circ} \mathrm{C}$, which is an increase of only $26^{\circ} \mathrm{C}$ in relation to the temperature of the exhaust gas measured upstream from the TWC. 


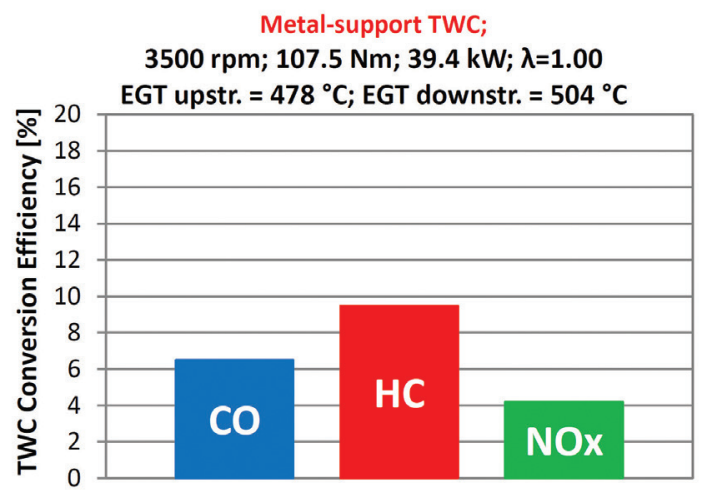

Fig. 21. The efficiency of conversion of the TWC with a metal support during operation of a five-stroke engine with a rotational speed of $3500 \mathrm{rpm}$ and a load of $107.5 \mathrm{Nm}$

\subsection{Warm-up process of the TWC with a ceramic support}

In the last phase of the tests that are the subject of this paper, tests on the warming up of the catalytic converter with the ceramic support were performed. The research began from the cold start of the engine, through idle run and then run with various increasing partial load values up to achieving a throttle opening of $29 \%$ after 130 seconds, which allows the generation of torque of over $70 \mathrm{Nm}$. The value of the target load was selected on the basis of previously conducted quasi-stationary tests of the catalytic converter operation. The goal was to get the effect of lightoff the converter after about 150 seconds after reaching the final engine load. This enabled the convenient registration of the moment of starting the reactor operation and then obtaining its target activity. A fixed rotational speed of 2,000 rpm, a stoichiometric mixture and an ignition timing set to the maximum brake torque were applied. In this test of the five-stroke engine, the composition of exhaust gas only downstream the catalytic converter was measured. The test was performed until the stable temperature was measured downstream from the converter, which occurred just over eight minutes after the start of the cold engine.

Fig. 22 shows an illustration of the conditions for conducting the test of warming up the catalytic converter with a ceramic support. The chart presents throttle opening, generated torque and engine rotational speed as a function of time.

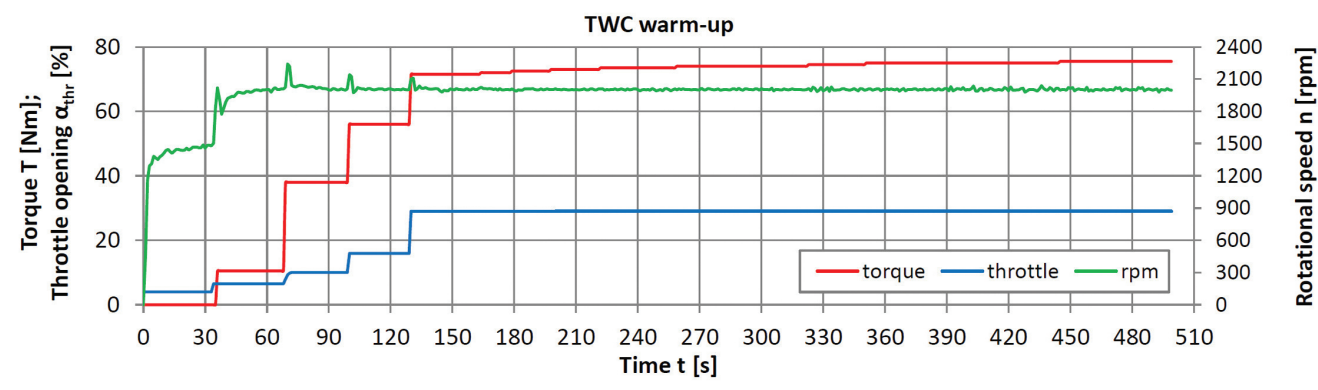

Fig. 22. Conditions for conducting the test of warming up the TWC with a ceramic support 
The increase in load from the moment the engine started to the desired value was graded so as to avoid operation of the cold engine under a high load, which is disadvantageous due to durability. As with the previous tests, the engine was running at a speed of 2,000 rpm. Only in the first phase of the idle engine operation was the rotational speed around $1,500 \mathrm{rpm}$.

Fig. 23 presents graphs of exhaust gas temperature measured upstream and downstream from the catalytic converter, and oxygen volume concentration and relative air-fuel ratio in the warming-up phase of the catalytic converter.

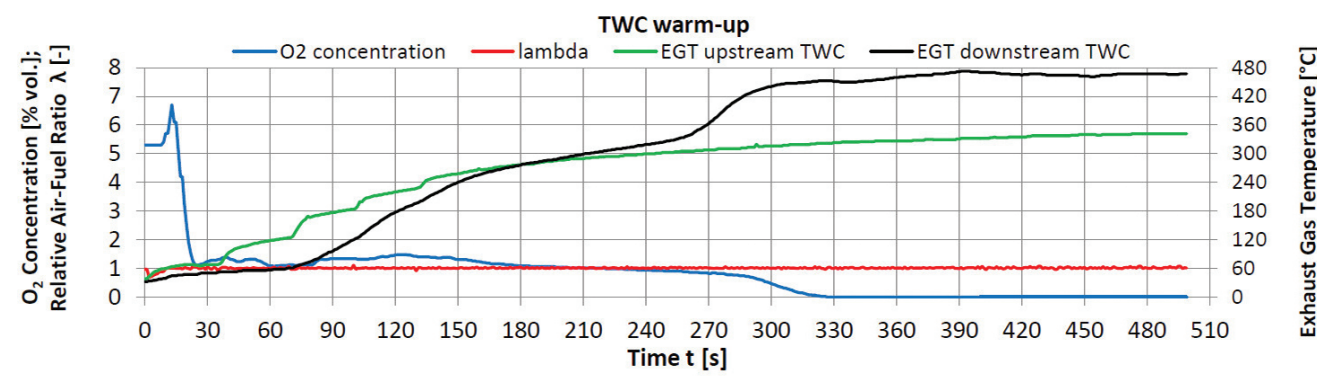

Fig. 23. Charts of exhaust gas temperature upstream and downstream from the catalytic converter, and oxygen volume concentration and relative air-fuel ratio measured in the warming-up phase of the catalytic converter

The effective work of the catalytic converter commenced around 260 seconds after the engine was started. A marked increase in the temperature downstream from the catalytic converter was then recorded. This fact corresponds with a reduction of the oxygen concentration in the exhaust downstream from the converter to a value close to zero. The oxygen concentration graph is delayed by around 20 seconds in relation to the temperature plot downstream from the converter, which results from the length of the pipe connecting the engine exhaust with the analyser and from the measurement properties of the analyser itself. After reaching the light-off temperature, the exhaust gas temperature increase in the TWC was around $130^{\circ} \mathrm{C}$ on average.

The plots of changes in the volume concentration of $\mathrm{CO}, \mathrm{CO}_{2}, \mathrm{HC}$ and $\mathrm{NO}_{\mathrm{x}}$ in the exhaust gas of the five-stroke engine during the test of the process of warming-up the TWC with a ceramic support are shown in Fig. 24.

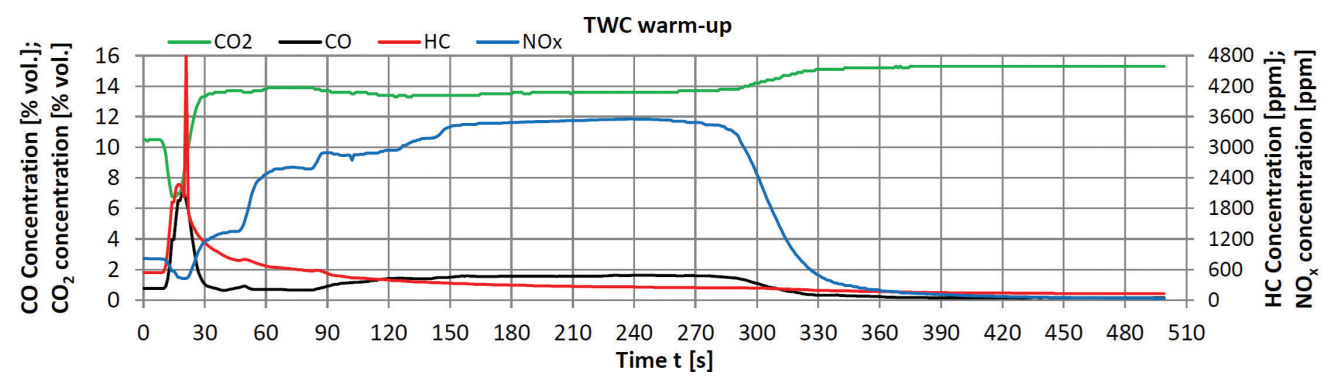

Fig. 24. Charts of the volume concentration of $\mathrm{CO}, \mathrm{CO}_{2}, \mathrm{HC}$ and $\mathrm{NO}_{x}$ in the exhaust gas of the five-stroke engine during the test of the process of warming-up the TWC with a ceramic support 
Achieving a volume concentration of carbon dioxide in the exhaust gas equal to $15.5 \%$ downstream from the converter means that it achieved a temperature sufficient for efficient operation. As in the case of oxygen concentration, all charts of volume concentration presented in Fig. 24 are delayed by 20 seconds in relation to the temperature waveform measured downstream from the converter. The sudden increase in the volume concentration of hydrocarbons in the exhaust gas in the $20^{\text {th }}$ second of measurement to over $4,800 \mathrm{ppm}$ results from the misfire in the first cycle of operation after starting the five-stroke engine. The volume concentration of $\mathrm{HC}$ before the active operation of the catalytic converter was around $250 \mathrm{ppm}$. After the converter started to operate, the concentration of HC dropped to around $130 \mathrm{ppm}$, which means obtaining a relatively good conversion efficiency in the analysed case. The results of starting the effective operation of the catalytic converter are best seen in the course of the volume concentration of nitrogen oxides in the exhaust gas. Before activating the reactor, it was around 3,600 ppm, after light-off it dropped to around $35 \mathrm{ppm}$.

Due to the fact that the converter with a metal support that was selected for the research did not show sufficiently effective work in quasi-stationary tests, conducting the test of its warming-up process was pointless; therefore, no such test was performed.

\subsection{Efficiency and performance of the engine with TWC}

The converters used for research have clearly different constructional features. The differences mainly boil down to the materials of which the supports were made, and also to the cell density and support dimensions. The reactor with a metal support has a significantly lower cell density, moreover, the walls of the metal support have a smaller thickness than in the case of the ceramicsupport converter. All this means that a metal-support TWC should cause lower resistance to the exhaust gas flow, and consequently, for the same engine operating conditions, the backpressure in the exhaust system should be lower. As mentioned earlier, increasing the backpressure in the exhaust system limits the effects of using additional exhaust expansion. Figure 25 presents a comparison of fuel consumption $[\mathrm{kg} / \mathrm{h}]$ and brake specific fuel consumption $[\mathrm{g} / \mathrm{kWh}]$ of the fivestroke engine cooperating with ceramic-support and metal-support converters. The comparison is presented as a function of the engine load represented by the torque.

Analysis of the comparison shows that the use of a metal-support reactor for the five-stroke engine allows reduction of the specific fuel consumption in relation to the values obtained with the ceramic-support converter. The entire line of the BSFC obtained with the metal-support converter is located below the line registered when the engine worked with a ceramic-support converter. The minimum recorded specific fuel consumption values were equal to $256.5 \mathrm{~g} / \mathrm{kWh}$ when operating with a ceramic-support catalytic converter and $253.6 \mathrm{~g} / \mathrm{kWh}$ when using a metal-support reactor in the exhaust system. The reduction of the brake specific fuel consumption results mainly from the increase of the torque obtained by the engine for the given operating conditions. The values of fuel consumption $[\mathrm{kg} / \mathrm{h}]$ remained at a comparable level. The obtained results confirm predictions about the possibility of obtaining a reduction in specific fuel consumption using a catalytic converter with lower exhaust flow resistance. The lower backpressure in the exhaust system limits to a lesser extent the positive effects of additional expansion. 


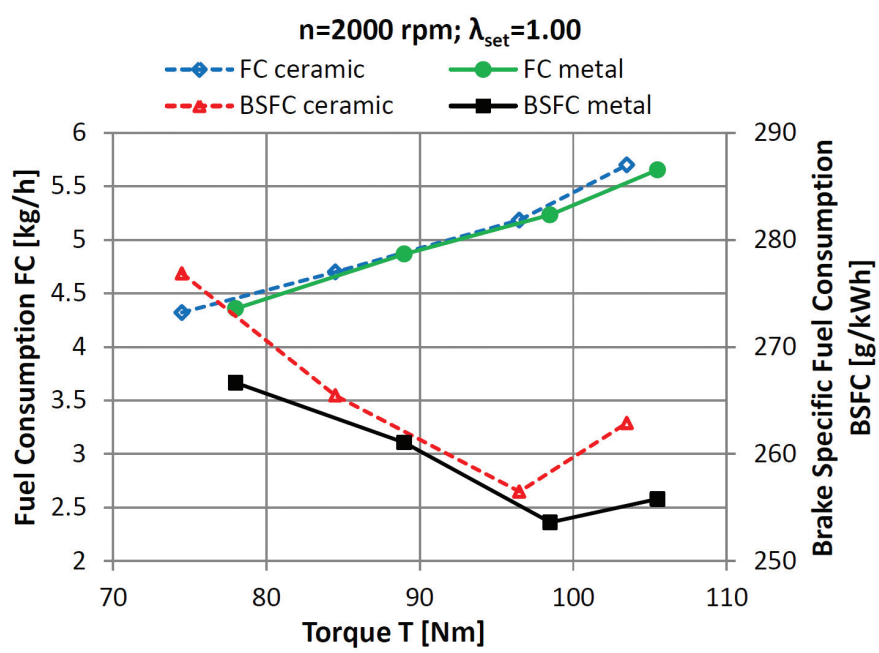

Fig. 25. Comparison of fuel consumption $[\mathrm{kg} / \mathrm{h}]$ and brake specific fuel consumption $[\mathrm{g} / \mathrm{kWh}]$ of the five-stroke engine cooperating with ceramic-support and metal-support converters as a function of the engine load

\section{Discussion}

The analysis of the research results showed that the effective exhaust gas aftertreatment at low load and low rotational speed is impossible. At medium and high loads, the acceptable operation of the TWC with a ceramic-support was observed. The applied ceramic reactor demonstrated correct operation from the exhaust gas temperature of approx. $280^{\circ} \mathrm{C}$, which corresponds to a BMEP value of 2.5 bar at $2000 \mathrm{rpm}$. The tested metal-support reactor was not functional even with increased load and rotational speed when the exhaust temperature was already around $480^{\circ} \mathrm{C}$. This fact gives reason for stating that the tested catalytic converter with a metal support obtained low conversion efficiency of toxic exhaust components due to the insufficient amount of precious metals used to make it. Unfortunately, the manufacturer of the converter did not reveal any data other than cell density and support dimensions.

In order to obtain an acceptable conversion efficiency of toxic exhaust components in the tested converter with a ceramic support, it is essential that, first of all, the regulation of the mixture composition occurs within a very narrow range of changes in the lambda value around the stoichiometric composition. In this situation, conversion efficiency of a high value is achieved, especially for nitrogen oxides and carbon monoxide; a lower value is achieved for hydrocarbons. The lower conversion efficiency for hydrocarbons than carbon monoxide or $\mathrm{NO}_{x}$ results from the generally low temperature of exhaust gases entering the converter. At an exhaust gas temperature of around 340 to $360^{\circ} \mathrm{C}, \mathrm{HC}$ conversion efficiency may be lower than the $\mathrm{NO}_{\mathrm{x}}$ result by 25 to as much as $40 \%$ [26]. A certain improvement in the efficiency of exhaust gas aftertreatment could be achieved by using a catalytic converter with newly developed support materials in the form of a mixture of $\mathrm{Al}_{2} \mathrm{O}_{3} / \mathrm{CeO}_{2} / \mathrm{ZrO}_{2}$ oxides. Converters with the used new support material show a significantly reduced activation temperature compared 
to the previously used converters with the thus-far popular material mix of $\mathrm{Al}_{2} \mathrm{O}_{3}+\mathrm{CeO}_{2}$ / $\mathrm{ZrO}_{2}$ oxides. Such converters are designed for use in vehicles with highly efficient SI engines with direct injection in which the exhaust temperature is significantly lower than for older engines $[9,47]$.

From the moment of starting the cold engine to achieving the active operation of the catalytic converter in the adopted load variability regime, more than 300 seconds elapsed. From the moment the engine got the target load to a start of converter operation about 165 seconds elapsed. The low temperature of the exhaust gases after additional expansion causes that the heating of the reactor to the light-off temperature takes a relatively long time. Shortening the warming-up period of a three-way catalytic converter requires limiting the operating period with a low load to a minimum. The limit here is mainly the durability of the engine, and the determination of the minimum allowable time for preheating the engine at low load would require wider operational tests in this regard.

The use of non-hardware exhaust gas temperature increasing techniques, for example by ignition retarding, is not very effective in the engine with additional exhaust expansion. The performed tests have shown that although the ignition retarding increases the temperature of exhaust gases leaving the fired cylinders in a similar manner to the classical engine, it does not, however, translate into a proportional increase in the exhaust gas temperature downstream from the low pressure cylinders. The effects of the ignition retarding are wasted by the intensified heat dissipation through the exhaust to the walls of the additional expansion cylinders and to the elements of the engine exhaust system. The costs of increasing the temperature of the exhaust gases by the ignition retarding are relatively high. The research indicated that the increase of exhaust gas temperature at the inlet to the converter by approx. $15^{\circ} \mathrm{C}$ was associated with an increase in the specific fuel consumption by $34 \mathrm{~g} / \mathrm{kWh}$, which translates to as much as $12 \%$.

The use of the catalytic converter with a metal support of a lower cell density and the subsequent lower flow resistance resulted in increasing the torque of the five-stroke engine at the same boost pressure. The minimum value of the obtained specific fuel consumption is about $3 \mathrm{~g} / \mathrm{kWh}$ lower than in case of cooperation of the five-stroke engine with the ceramicsupport reactor. Unfortunately, as mentioned earlier, no symptoms of the effective operation of this metal-support reactor were found, even at the exhaust gas temperature of $480^{\circ} \mathrm{C}$, which disqualifies it as a device for the aftertreatment of engine exhaust.

\section{Conclusions}

The low exhaust temperature of the engine with additional expansion means that the development of the exhaust aftertreatment system encounters problems which are absent in the case of conventional spark-ignition engines. The tested converter with the ceramic support fulfilled its functions in a correct manner. Acceptable levels of conversion efficiency of the converter were obtained under the quasi-stationary operating conditions of the engine. The requirement for correct operation of the reactor is exceeding an exhaust gas temperature 
of $280^{\circ} \mathrm{C}$, which is obtained with a load of $2.5 \mathrm{bar}$ BMEP and a rotational speed of 2,000 rpm. Under these conditions, the ceramic-support catalytic converter was working properly; however, at low load after a cold start, warming up of the reactor to a light-off temperature would be extremely long. The reduction of exhaust emissions due to the reactor did not reach the nominal operating temperature requires the engine to enter the work area with a high load as quickly as possible. To obtain high values of conversion efficiency in TWC, it is also necessary to precisely adjust the composition of the mixture to a value of $\lambda=1.0$. Deviations from this value by even 0.02 cause a significant reduction in the exhaust gas cleaning efficiency, especially in the area of hydrocarbon oxidation. The effect of shortening the warming-up phase of the catalytic converter to the operating temperature by increasing the temperature of exhaust gases internally in the engine is weakened by intensified heat exchange with the walls of the additional expansion cylinders and elements of the engine exhaust system. In order to substantially shorten the warming up time of a catalytic converter, the use of an external, hardware method, such as the use of electric heating of the reactor support, should be considered and balanced [25, 42]. Another idea is the relocation of the catalytic converter upstream from the turbine. The exhaust gas temperature is at least $50^{\circ} \mathrm{C}$ higher than that measured downstream from the turbine, which would contribute to a faster achievement of the effective operation of the catalytic converter [8]. In addition, an increase in the temperature of the exhaust gas in the catalytic converter resulting from the exothermic nature of the reactions occurring inside could improve the operating conditions of the turbine, which operates in a five-stroke engine at a relatively low temperature. For similar reasons, it is also possible to apply a catalytic layer on the walls of ports connecting the fired cylinders with low pressure cylinders, which would increase the exhaust gas temperature and improve the process of additional expansion [4].

The use of the metal-support reactor with reduced exhaust flow resistance resulted in a reduction in the specific fuel consumption of the five-stroke engine. The converter itself did not show proper functionality in aftertreatment due to the probable low content of precious metals used in its support; however, during the research, the potential possibilities of reducing fuel consumption by the engine cooperating with the reactor with low flow resistance were outlined. This means that further search for a suitable converter should be performed in the future.

The presented research and analysis results confirm the findings of previous works in which the five-stroke engine was defined as a source of propulsion suitable for cooperation with an electric power generator, for example, as a range-extender [34]. In such an application, the engine operates in fixed conditions with a high load. In classic vehicle drive systems, where the combustion engine is the sole source of propulsion, this character of the work is, by nature, impossible to achieve. The engine often works with a low load, which in the case of a five-stroke engine, is highly unfavourable due to its fuel conversion efficiency, as well as the conversion efficiency of the exhaust gas aftertreatment system with the TWC converter.

This research was conducted in the framework of task No. M-04/406/2018/DS, which was a subsidy for research granted by the Ministry of Science and Higher Education of the Republic of Poland. 


\section{References}

[1] Adachi S., Hagihara H., The renewed 4-Cylinder Engine Series for Toyota Hybrid System, Fortschritt-Berichte VDI Reihe 12, vol. 749, 2012, 1-24.

[2] Ailloud C., Delaporte B., Schmitz G., Keromnes A., Le Moyne L., Development and Validation of a Five Stroke Engine, SAE Technical Paper 2013-24-0095, 2013, 10.4271/2013-24-0095.

[3] Ajanovic A., Biofuels versus food production: Does biofuels production increase food prices?, Energy vol. 36(4), 2011, 2070-2076, 10.1016/j.energy.2010.05.019.

[4] Andrych-Zalewska M., Improving the environmental performance of the internal combustion engine by the use in-cylinder catalyst, Combustion Engines, vol. 168(1), 2017, 129-132, 10.19206/CE-2017-120.

[5] Brettschneider J., Berechnung des Luftverhältnisses von Luft-Kraftstoff-Gemischen und des Einflusses von Meßfehlern aufLambda, Bosch Technische Berichte, vol. 6(4), 1979, 177-186.

[6] Brooke L., Not dead yet: The resilient ICE looks to 2050, Automotive Engineering, vol. 5(4), 2018, 22-23.

[7] Brzeżański M., Mareczek M., Marek W. et al., The realized concept of variable chemical composition fuel gas supply systems, for internal combustion engines, Combustion Engines, vol. 170(3), 2017, 108-114, 10.19206/CE-2017-318.

[8] Carberry B., Grasi G., Guerin S., Jayat F. et al., Pre-Turbocharger Catalyst - Fast catalyst light-off evaluation, SAE Technical Paper 2005-01-2142, 2005, 10.4271/2005-01-2142.

[9] Chen H.-Y., Chang H.-L., Development of Low Temperature Three-Way Catalysts for Future Fuel Efficient Vehicles, Johnson Matthey Technol. Rev., vol. 59 (1), 2015, 64-67, $10.1595 / 205651315 X 686011$.

[10] Cummins C.L., Internal fire, Carnot Press, Wilsonville 2000.

[11] Czerwinski J., Zimmerli Y., Hüssy A. et al., Testing and evaluating real driving emissions with PEMS, Combustion Engines, vol. 173(4), 2018, 17-25, 10.19206/CE-2018-302.

[12] Dumböck O., Schutting E., Eichlseder H., Extended expansion linkage engine: a concept to increase the efficiency, Automotive and Engine Technology, vol. 3, 2018, 83-92, 10.1007/ s41104-018-0029-9.

[13] Eichlseder H., Klüting M., Piock W.F., Grundlagen und Technologien des Ottomotors: Der Fahrzeugantrieb, Springer, Vienna 2008.

[14] Fuć P., Merkisz J., Lijewski P. et al., Exhaust emission in NEDC test simulated at a dynamic engine test bed, Combustion Engines, vol. 154(3), 2013, 701-707.

[15] Gaines L., The future of automotive lithium-ion battery recycling: Charting a sustainable course, Sustainable Materials and Technologies, vol. 1-2, 2014, 2-7, 10.1016/j. susmat.2014.10.001.

[16] Gęca M.S., Rybak A., Hunicz J., A simulation study into the Atkinson cycle engine utilizing adjustable crank mechanism, IOP Conf. Ser.: Mater. Sci. Eng., vol. 421, 042021, 10.1088/1757-899X/421/4/042021.

[17] Goto T., Hatamura K., Takizawa S., Hayama N. et al., Development of V6 Miller Cycle Gasoline Engine, SAE Technical Paper 940198, 1994, 10.4271/940198. 
[18] Goto T., Isobe R., Yamakawa M., Nishida M., The New Mazda Gasoline Engine Skyactiv-G, MTZ Worldwide, vol. 72(6), 2011, 40-47, 10.1365/s38313-011-0063-8.

[19] Hedingerm R., Elbert P., Onder C., Optimal Cold-Start Control of a Gasoline Engine, Energies, vol. 10(10), 2017, 1548, 10.3390/en10101548.

[20] Hwang I., Lee H., Park H. et al., Hyundai-Kia's Highly Innovative 1.6L GDI Engine for Hybrid Vehicle, Fortschritt-Berichte VDI, Reihe 12: Verkehrstechnik/Fahrzeugtechnik, vol. 799, 2016, 285-303.

[21] Iskra A., BabiakM., WróblewskiE., The problems of piston skirtmicrogeometry in combustion engines, IOP Conf. Ser.: Mater. Sci. Eng., vol. 148, 2016, 012068, 10.1088/1757899X/148/1/012068.

[22] Jääskeläinen H., Miller Cycle Engines, https://www.dieselnet.com/tech/engine_millercycle.php (access: 09.11.2018).

[23] Johnson T.V., Joshi A., Directions in vehicle efficiency and emissions, Combustion Engines, vol. 166(3), 2016, 3-8, 10.19206/CE-2016-306.

[24] Kéromnès A., Delaporte B., Schmitz G., Le Moyne L., Development and validation of a 5 stroke engine for range extenders application, Energy Convers. Manag., vol. 82, 2014, 259-267, 10.1016/j.enconman.2014.03.025.

[25] Kessels J.T.B.A., Foster D.L., Bleuanus W.A.J., Fuel Penalty Comparison for (Electrically) Heated Catalyst Technology, Oil \& Gas Science and Technology - Rev. IFP, vol. 65, No. 1, 2010, 47-54, 10.2516/ogst/2009078.

[26] Kruczyński S.W., Danilczyk W., Ograniczanie szkodliwości gazów wylotowych silników spalinowych poprzez zastosowanie reaktorów katalitycznych, MOTROL Motoryzacja i Energetyka Rolnictwa, vol. 9, 2007, 93-102.

[27] Leman A.M., Rahman F., Jajuli A., Zakaria S., Feriyanto D., Emission Treatment towards Cold Start and Back Pressure in Internal Combustion Engine against Performance of Catalytic Converter: A Review, MATEC Web of Conferences vol. 87, 2017, 02021, $10.1051 /$ matecconf/20178702021.

[28] Li T., Wang B., Zheng B., A comparison between Miller and five-stroke cycles for enabling deeply downsized, highly boosted, spark-ignition engines with ultra expansion, Energy Convers. Manage., vol. 123, 2016, 140-152.

[29] Lind W.L., Internal-Combustion Engines: Their Principles and Applications to Automobile, Aircraft, and Marine Purposes, Ginn, Boston 1920, 3-4.

[30] Malcev V., Bozhenov A., Schwab R., Müther M., High Power Density High Speed Diesel, MTZ industrial, vol. 6(2), 2016, 14-21, 10.1007/s40353-016-0013-7.

[31] Miller R.H., Supercharging and internal cooling cycle for high output, ASME Trans. vol. 69(4) 1947, 453-464.

[32] Miller R.H, High expansion, spark ignited, gas burning, internal combustion engines, USA Patent 2773 490, 11 December 1956.

[33] Mizuno H., Nissan gasoline engine strategy for higher thermal efficiency, Combustion Engines, vol. 169(2), 2017, 141-145, 10.19206/CE-2017-225.

[34] Noga M., Application of VNT Turbocharger in Spark Ignition Engine with Additional Expansion of Exhaust Gases, Technical Gazette vol. 25(6), 2018, 1575-1580, 10.17559/ TV-20160211230747. 
[35] Noga M.,Five-strokeInternal Combustion Engine-yesterday, today and tomorrow, IOP Conf. Ser.: Mater. Sci. Eng., vol. 421, 2018, 042058, 10.1088/1757-899X/421/4/042058.

[36] Noga M., Selected Issues of the Indicating Measurements in a Spark Ignition Engine with an Additional Expansion Process, Appl. Sci., vol. 7(3), 2017, 295, 10.3390/app7030295.

[37] Noga M., Various aspects of research of the SI engine with an additional expansion process, MATEC Web of Conferences, vol. 118, 2017, 00017, 10.1051/matecconf/ 201711800017.

[38] Noga M., Juda Z., Energy efficiency and equivalent CO2 emissions of a light-duty electric vehicle depending on driving distance, IOP Conf. Ser.: Mater. Sci. Eng., vol. 421, 2018, 022023, 10.1088/1757-899X/421/2/022023.

[39] Noga M., Sendyka B., Determination of the Theoretical and Total Efficiency of the FiveStroke SI Engine, Int J Automot Technol., vol. 15(7), 2014, 1083-1089, 10.1007/ s12239-014-0112-9.

[40] Noga M., Sendyka B., Increase of efficiency of SI engine through the implementation of thermodynamic cycle with additional expansion, Bulletin of the Polish Academy of Sciences Technical Sciences, vol. 62(2), 2014, 349-355, 10.2478/bpasts-2014-0034.

[41] Noga M., Sendyka B., New design of the five-stroke SI engine, Journal of KONES vol. 20(1), 2013, 239-246, 10.5604/12314005.1136161.

[42] Pace L., Presti M., An Alternative Way to Reduce Fuel Consumption During Cold Start: The Electrically Heated Catalyst, SAE Technical Paper 2011-24-0178, 2011, 10.4271/201124-0178.

[43] Pielecha I., Cieślik W., Borowski P. et al., The development of combustion engines for hybrid drive systems, Combustion Engines, vol. 158(3), 2014, 23-35.

[44] Pielecha I., Cieślik W., Szałek A., The use of electric drive in urban driving conditions using a hydrogen powered vehicle - Toyota Mirai, Combustion Engines, vol. 172(1), 2018, 51-58, 10.19206/CE-2018-106.

[45] Sass F., Geschichte des deutschen Verbrennungsmotorenbaues - Von 1860 bis 1918, Springer, Berlin-Göttingen-Heidelberg 1962.

[46] Shuai S., Ma X., Li Y. et al., Recent Progress in Automotive Gasoline Direct Injection Engine Technology, Automot. Innov., vol. 1(2), 2018, 95-113,10.1007/s42154-018-0020-1.

[47] Theis J., Getsoian A., Lambert C., The Development of Low Temperature Three-Way Catalysts for High Efficiency Gasoline Engines of the Future, SAE Int. J. Fuels Lubr., vol. 10(2), 2017, 583-592, 10.4271/2017-01-0918.

[48] Wojciechowski K.T., Merkisz J., Fuć P. et al., Prototypical thermoelectric generator for waste heat conversion from combustion engines, Combustion Engines, vol. 154(3), 2013, 60-71.

[49] Żmudka Z., Postrzednik S., Przybyła G., Realization of the Atkinson-Miller cycle in spark-ignition engine by means of the fully variable inlet valve control system, Archives of Thermodynamics, vol. 35 (3), 2014, 191-205, 10.2478/aoter-2014-0029. 